\title{
WestVirginiaUniversity
}

THE RESEARCH REPOSITORY @ WVU

Graduate Theses, Dissertations, and Problem Reports

2013

\section{Development of Synthetic Pathways for Macrocyclic Acetylenes}

\author{
Chi-Yuan Tseng \\ West Virginia University
}

Follow this and additional works at: https://researchrepository.wvu.edu/etd

\section{Recommended Citation}

Tseng, Chi-Yuan, "Development of Synthetic Pathways for Macrocyclic Acetylenes" (2013). Graduate Theses, Dissertations, and Problem Reports. 3623.

https://researchrepository.wvu.edu/etd/3623

This Thesis is protected by copyright and/or related rights. It has been brought to you by the The Research Repository @ WVU with permission from the rights-holder(s). You are free to use this Thesis in any way that is permitted by the copyright and related rights legislation that applies to your use. For other uses you must obtain permission from the rights-holder(s) directly, unless additional rights are indicated by a Creative Commons license in the record and/ or on the work itself. This Thesis has been accepted for inclusion in WVU Graduate Theses, Dissertations, and Problem Reports collection by an authorized administrator of The Research Repository @ WVU. For more information, please contact researchrepository@mail.wvu.edu. 
Development of Synthetic Pathways for Macrocyclic Acetylenes

\title{
Chi-Yuan Tseng
}

Thesis submitted to the

Eberly College of Arts and Sciences

at West Virginia University

In partial fulfillment of the requirements

for the degree of

\author{
Master of Science \\ in
}

Chemistry

\author{
Kung K. Wang, Ph. D., Chair \\ Jeffrey L. Petersen, Ph. D. \\ Björn C. G. Söderberg, Ph. D.
}

C. Eugene Bennett Department of Chemistry

Morgantown, West Virginia

2013

Keywords: Macrocyclic Acetylenes, Schmittel Cyclization

Copyright 2013 Chi-Yuan Tseng 


\begin{abstract}
A synthetic sequence was developed for the preparation of a diindeno-fused $4 \mathrm{H}$ cyclopenta[def]phenanthrene derivative containing two bromo substituents as a potential building block for the construction of macrocyclic acetylenes. The synthetic sequence required the preparation of a benzannulated enediyne, 1-bromo-2-ethynyl-3-(2phenylethynyl)benzene. The Sonogashira reaction between 1,3-dibromo-2-iodobenzene and (trimethylsilyl)ethyne produced 1,3-dibromo-2-[(trimethylsilyl)ethynyl]benzene. Metalhalogen exchange with $n$-butyllithium followed by iodination with iodine furnished 1-bromo3-iodo-2-[(trimethylsilyl)ethynyl]benzene. A second Sonogashira reaction with phenylethyne followed by desilylation then furnished 1-bromo-2-ethynyl-3-(2-phenylethynyl)benzene.

Treatment of an excess of 1-bromo-2-ethynyl-3-(2-phenylethynyl)benzene with lithium diisopropylamide followed by condensation with 2,2-dimethoxy-1,3-indandione furnished the corresponding propargylic diol as the major adduct and the corresponding mono-ol as the minor adduct. On exposure to thionyl chloride, the diol underwent a Schmittel cascade cyclization reaction to produce the diindeno-fused $4 H$-cyclopenta[def]phenanthrene derivative containing two bromo substituents. The presence of the two bromo substituents provides handles for additional Sonogashira reactions for the construction of macrocyclic acetylenes.
\end{abstract}


Dedicated To

My parents

and

My wife, Yi Ching Chen 


\section{ACKNOWLEDGMENTS}

I sincere appreciate my advisor, Dr. Kung K. Wang, for his guidance, support, patience, and encouragement during my graduate student life. Dr. Wang taught me the skills and abilities in chemistry, and inspired me to be a better person. I am very proud and grateful to be his student.

I would like to express gratitude to my research committee members, Dr. Jeffrey L. Petersen and Dr. Björn C. G. Söderberg for their helpful advice, guidance, and kindness. They helped me to expand my knowledge and think in a logical way.

I would also like to thank to Dr. Novruz Akhmedov for his generous assistance in NMR spectroscopy, and all my laboratory mates, Changfeng Huang, Yiwei Huang, and Yang-Sheng Sun for their assistance, and friendship throughout these years. The valuable discussions with them in the lab will be precious memories for me.

Financial support from C. Eugene Bennett Department of Chemistry at West Virginia University is gratefully acknowledged.

Finally, I would like to express my special appreciation to my family: my grandma, my parents, and my sister for their unconditional love and support; my wife, Yi-Ching Chen, for her unselfish love to me. 


\section{TABLE OF CONTENTS}

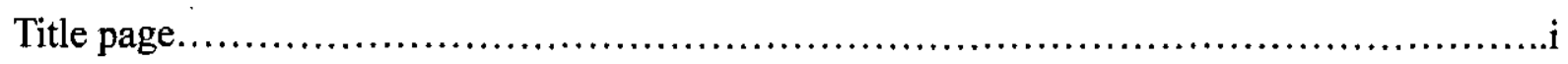

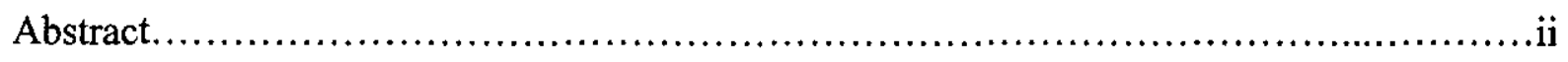

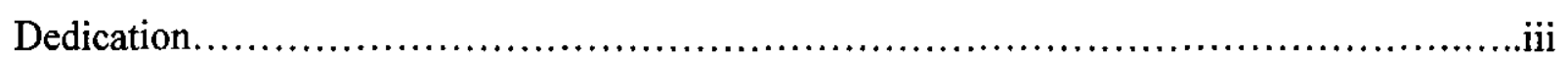

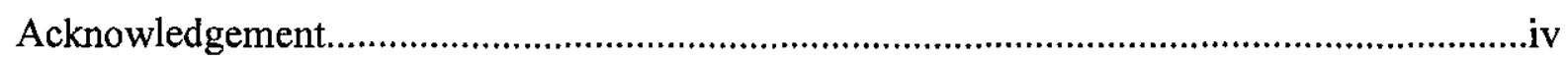

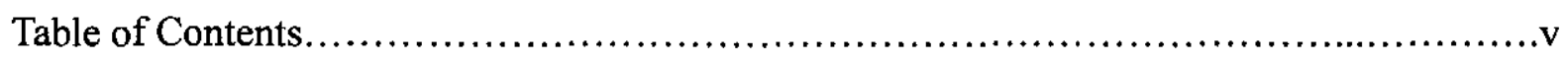

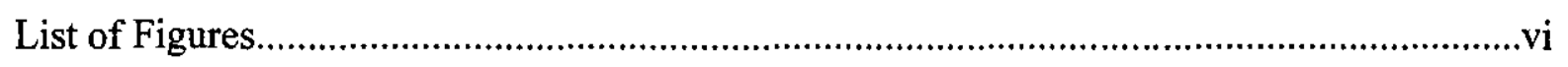

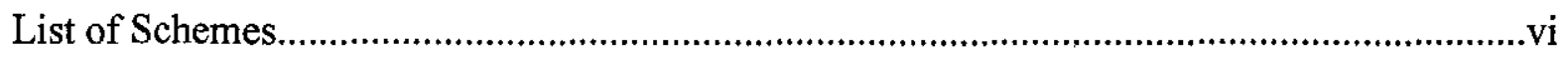

List of ${ }^{1} \mathrm{H}$ and ${ }^{13} \mathrm{C}$ NMR spectra.....................................................

\section{Part I}

\section{Development of Synthetic Pathways for Macrocyclic Acetylenes}

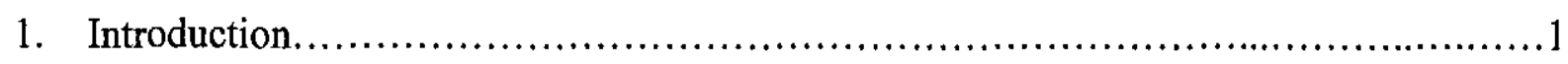

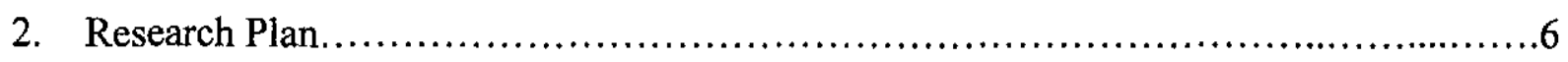

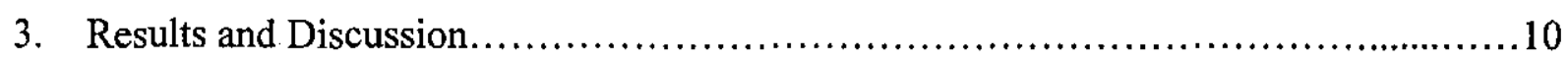

4. Conclusions.....................................................................

\section{Part II \\ Experimental Section}

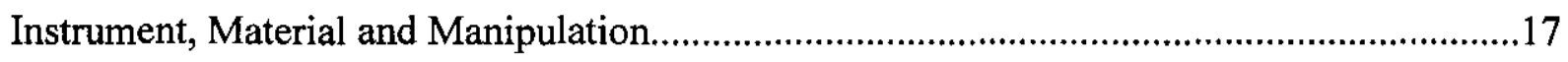

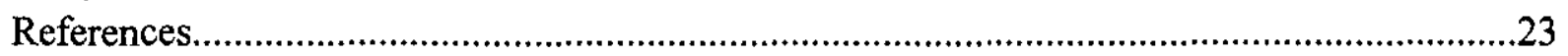

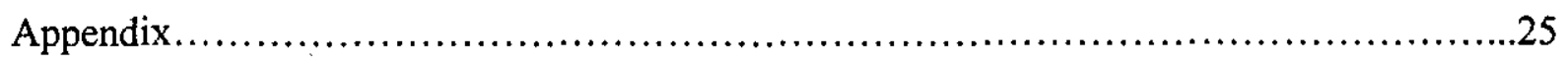

Approval of Examining Committee ....................................................40 


\section{LIST OF FIGURES}

Figure 1 Two examples of macrocyclic acetylenes..................................

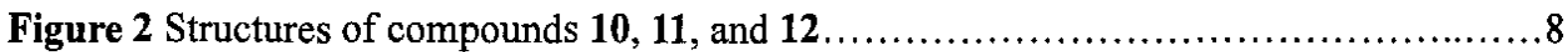

Figure 3 Structures of compounds $20 \mathrm{a}$ and $\mathbf{3 a}$ and the characteristic ${ }^{1} \mathrm{H}$ NMR signals.......14

Figure 4 Structures of compounds $24 \mathrm{a}$ and $\mathbf{2 4 b}$ and the characteristic ${ }^{1} \mathrm{H}$ NMR signals...... 16

\section{LIST OF SCHEMES}

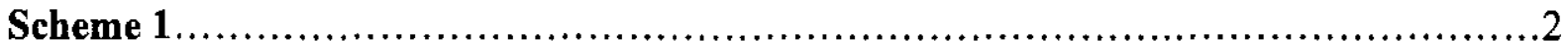

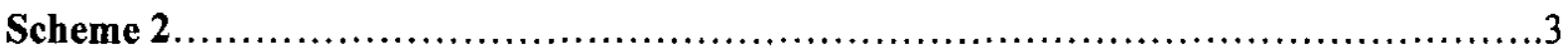

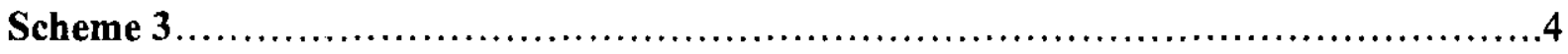

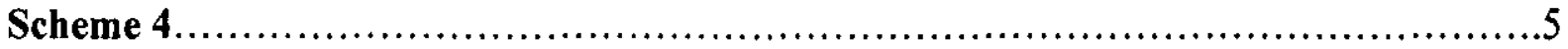

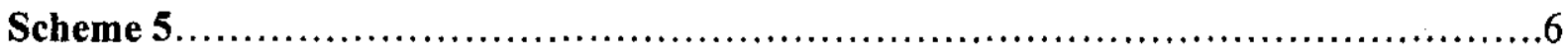

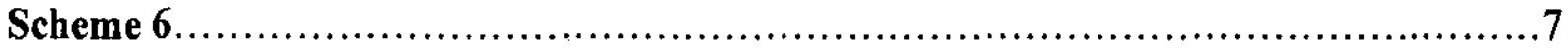

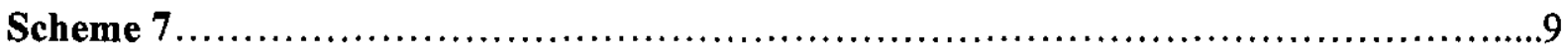

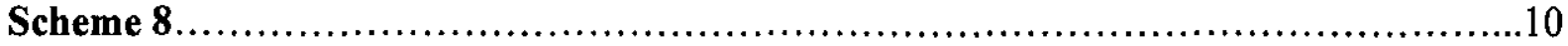

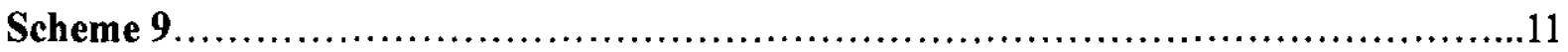

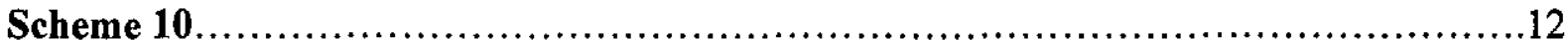

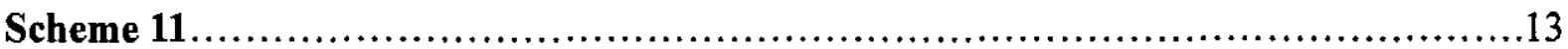

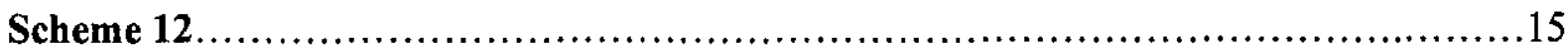




\section{LIST OF ${ }^{1} \mathrm{H}$ and ${ }^{13} \mathrm{C}$ NMR SPECTRA}

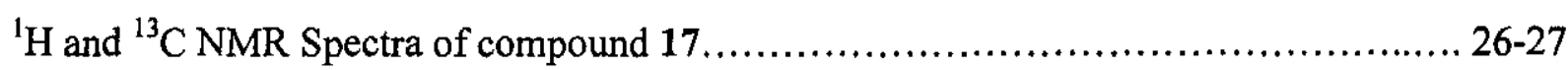

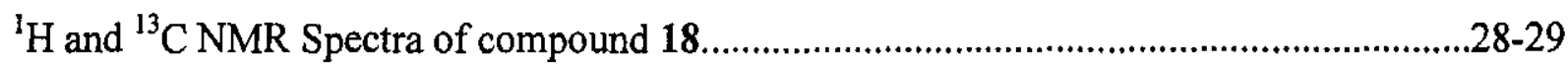

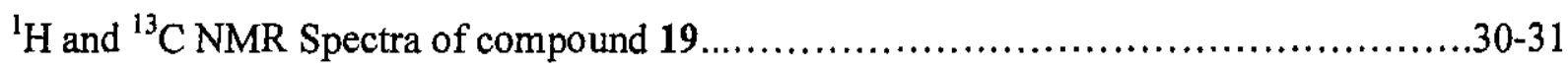

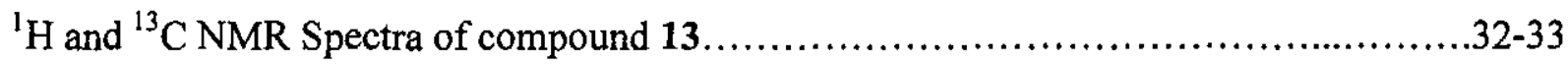

${ }^{1} \mathrm{H}$ and ${ }^{13} \mathrm{C}$ NMR Spectra of compound 20a ..........................................34-35

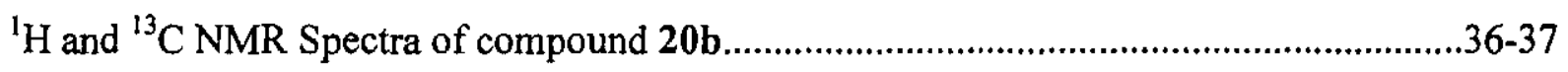

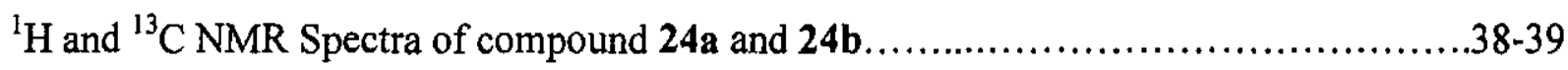




\section{Part I}

\section{Development of Synthetic Pathways for Macrocyclic Acetylenes}

\section{Introduction}

Macrocyclic acetylenes are a type of cyclic molecules that contain one or more acetylenic units as part of the cyclic structures. The presence of the acetylenic units and the linking carbon fragments highlight the features of macrocyclic acetylenes. Over the past few decades, macrocyclic acetylenes have been studied extensively for their physicochemical and supramolecular properties. ${ }^{1-6}$ Macrocyclic acetylenes contain special structural features, including the $\pi$ electron resonance of the acetylenic bonds, the molecular shape, the distorted electronic distribution, and the cavity inside the molecule. In addition, the exposed acetylenic chains make the macrocyclic acetylenes highly reactive. Based on these, macrocyclic acetylenes have been considered as potential intermediates for the synthesis of fullerenes. ${ }^{7}$
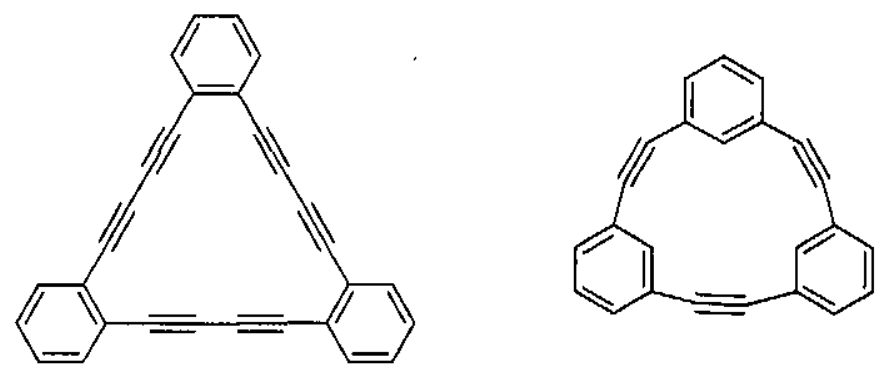

Figure 1 Two examples of macrocyclic acetylenes 
Several synthetic methods for the preparation of macrocyclic acetylenes have been reported, including bromination-dehydrobromination of the corresponding cycloalkenes (Scheme 1). ${ }^{8-10}$<smiles>BrC1c2ccccc2C(Br)C(Br)c2ccccc2C(Br)C(Br)c2ccccc21</smiles>

\section{Scheme 1}

This method represents a simple and efficient way to prepare macrocyclic acetylenes especially for strained cases. Most of the small macrocyclic acetylenes are prepared by this method. However, one of the limitations of this synthetic route is the difficulty in synthesizing cyclic alkenes as precursors for the corresponding macrocyclic acetylenes. The larger cycloalkene precursor are harder to prepare (Scheme 2). ${ }^{11,12}$ 

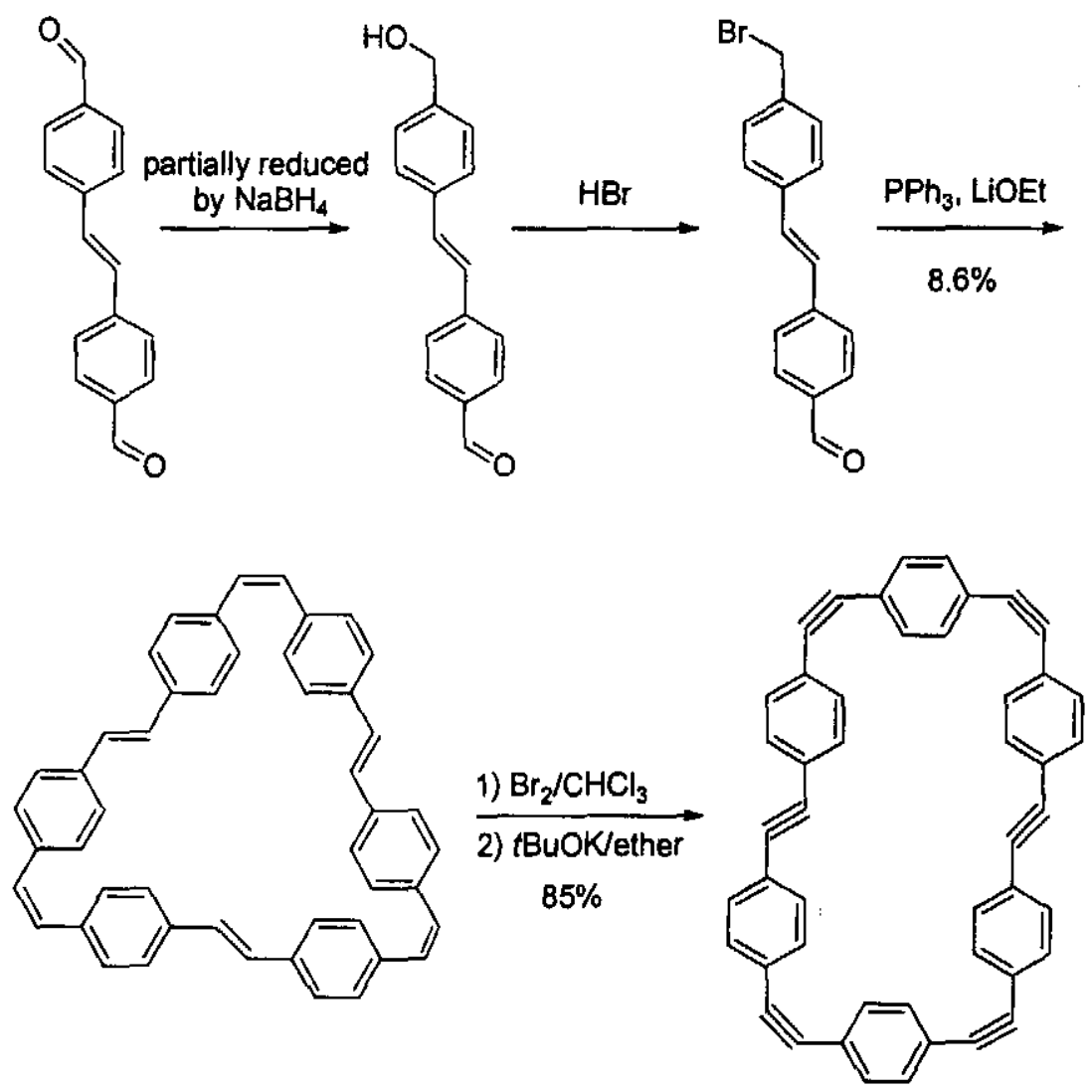

Scheme 2

On the other hand, coupling reactions have also found success in the preparation of macrocyclic acetylenes. In particular, the Sonogashira intra- or intermolecular coupling reaction ${ }^{13}$ has been adopted for the synthesis of a wide variety of macrocyclic acetylenes. For example, a series of cyclic [n]meta-phenylacetylenes $(n=5-7)$ have thus been synthesized (Scheme 3) ${ }^{14}$ However, the preparation of strained cases has been found to be very challenging using the coupling method. 
<smiles>[R]c1cc(I)cc(C#Cc2cc([R])cc(C#Cc3cc([R])cc(C#Cc4cc([R])cc(C#CC)c4)c3)c2)c1</smiles>

$\underset{\mathrm{Et}_{3} \mathrm{~N}}{\mathrm{Pd}(\mathrm{dba})_{2}, \mathrm{PPh}_{3}, \mathrm{Cul}}$

Scheme 3

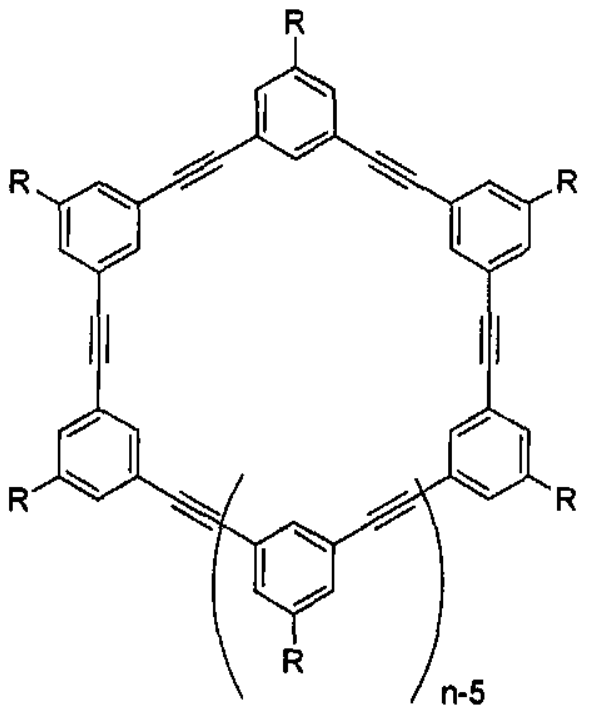

[n]meta-phenyleneacetylenes: $n=5-7$

Another interesting feature of macrocyclic acetylenes is the cavity inside the molecule. The synthesis of macrocyclic acetylenes could allow the construction of a large-sized carbon ring. With a large carbon ring, macrocyclic acetylenes could encapsulate one or more small molecules inside the cavity to form multi-inclusion type complexes (Scheme 4). ${ }^{15}$ In addition, the ring size and the shape of the linking carbon fragments could allow macrocyclic acetylenes to encapsulate only certain guest molecules selectively. 

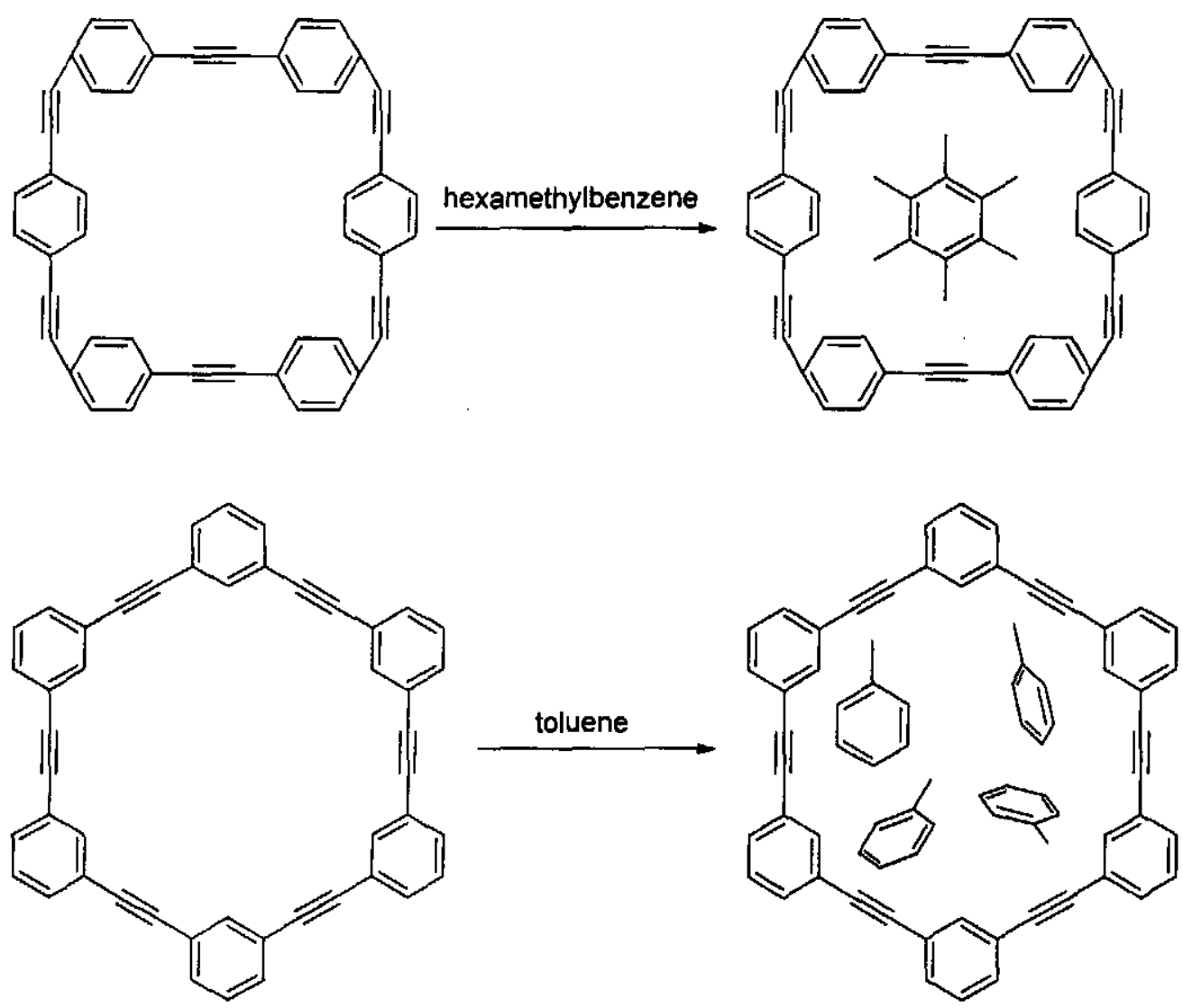

Scheme 4

Macrocyclic acetylenes with a planar $\pi$ electronic conjugate system inside the molecule have also been synthesized. This type of macrocyclic acetylenes has been used for the study of the electron-donating capability of the carbon fragment. A series of macrocyclic acetylenes adopting bicycle[2.2.2]octene (BCO) as the linking carbon fragment has been reported. The reduction potentials of these macrocyclic acetylenes showed that the lager the numbers of the $\mathrm{BCO}$ unit present in the molecule the easier it is to oxidize the molecule (Scheme 5). ${ }^{16}$ 


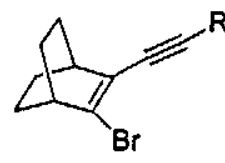
$\mathrm{R}=\mathrm{C}\left(\mathrm{CH}_{3}\right)_{2} \mathrm{OH}$
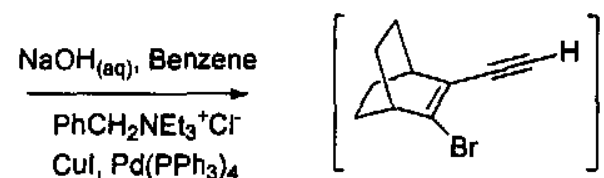

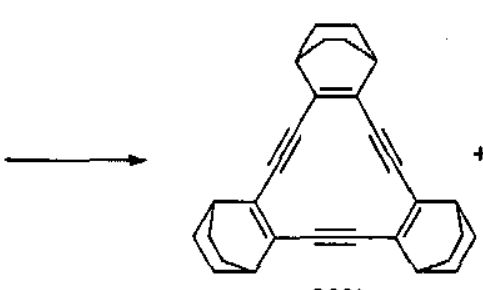

$22 \%$

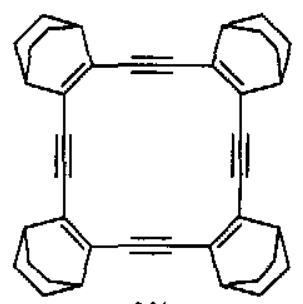

$9 \%$

\section{Scheme 5}

Because of their interesting structural features and potential applications in a variety of areas, macrocyclic acetylene continue to attract the attention of synthetic organic chemists with new design and synthesis of these molecules containing novel molecular architectures. ${ }^{17,18}$ Our goal in this research project is to provide new types of linking carbon fragments in the synthesis of macrocyclic acetylenes.

\section{Research Plan}

Our group previously reported an efficient route to produce highly unsaturated polycyclic aromatic compounds 7 and 8 from 2,2-dimethoxy-1,3-indandione (1) (Scheme 6). ${ }^{19}$ The 2,2-dimethoxy-1,3-indandione (1) was prepared from commercially available 2,2-dihydroxyindane-1,3-dione in one step. ${ }^{9}$ Condensation of diketone 1 with lithium acetylides 2 and 2 a produced benzannulated enediynyl alcohols 3 and 4, respectively. When the alcohols 3 and 4 were exposed to thionyl chloride, the cyclized dichlorides 5 and 6 were produced, respectively. Reduction of these dichlorides 5 and 6 with tributyltin 
hydride produced 7 in $46 \%$ yield and 8 in $47 \%$ yields for the last two steps. Likewise, diketone 9 was obtained by air oxidation of 6 in the presence of a $2 \mathrm{M} \mathrm{NaOH}$ solution.<smiles>COC1(OC)C(=O)c2ccccc2C1=O</smiles>

1

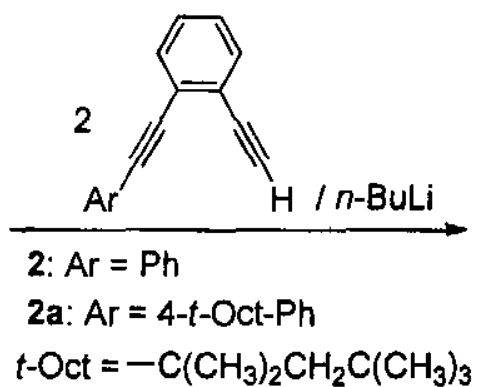

$t-\mathrm{Oct}=-\mathrm{C}\left(\mathrm{CH}_{3}\right)_{2} \mathrm{CH}_{2} \mathrm{C}\left(\mathrm{CH}_{3}\right)_{3}$

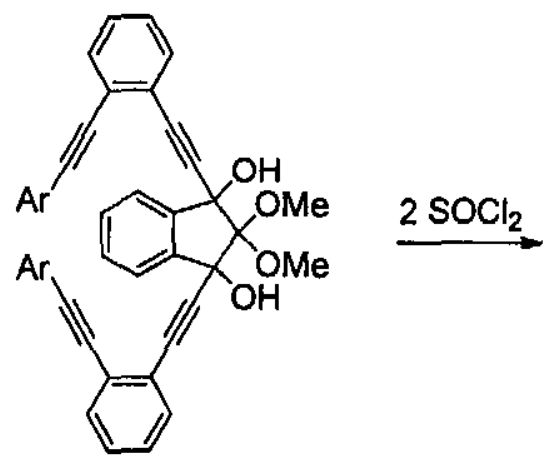

3: $\mathrm{Ar}=\mathrm{Ph}, 85 \%$

4: $\mathrm{Ar}=4-t-\mathrm{Oct}-\mathrm{Ph}, 84 \%$<smiles></smiles>

5: $\mathrm{Ar}=\mathrm{Ph}$

6: $\mathrm{Ar}=4-t-\mathrm{Oct}-\mathrm{Ph}$

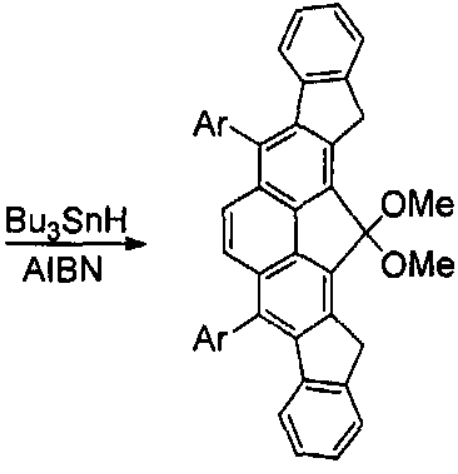

7: $\mathrm{Ar}=\mathrm{Ph}, 46 \%$ from 3

8: $\mathrm{Ar}=4-\mathrm{t}-\mathrm{Oct}-\mathrm{Ph}$, $47 \%$ from 4

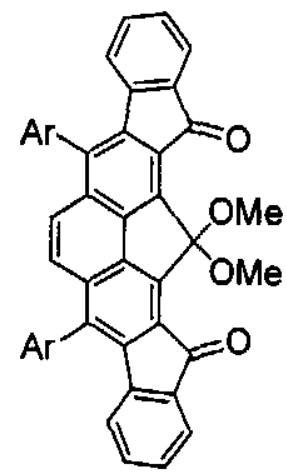

9: $\mathrm{Ar}=4-\mathrm{t}-$ Oct $-\mathrm{Ph}$, $45 \%$ from 4

\section{Scheme 6}

This research project will adopt the same synthetic strategy outlined in Scheme 6 for the preparation of 10 possessing two bromo substituents. The dibromide $\mathbf{1 0}$ could be further functionalized by using the Sonogashira reactions with 2 equivalents of (trimethylsilyl)acetylene, leading to diacetylene 11, with the two acetylenic groups in essentially parallel orientation. By repeating the Sonogashira reactions between $\mathbf{1 0}$ and 11, the macrocyclic acetylene 12 could thus be produced. The MM2-optimized structure 
of 12 shows that the aromatic carbon framework has a slight twist, but is essentially free of severely distorted bond angles. The two acetylenic groups remain essentially linear.<smiles></smiles>

10

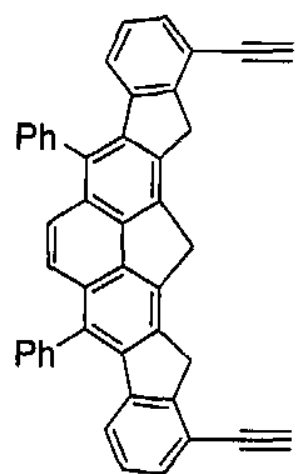

11

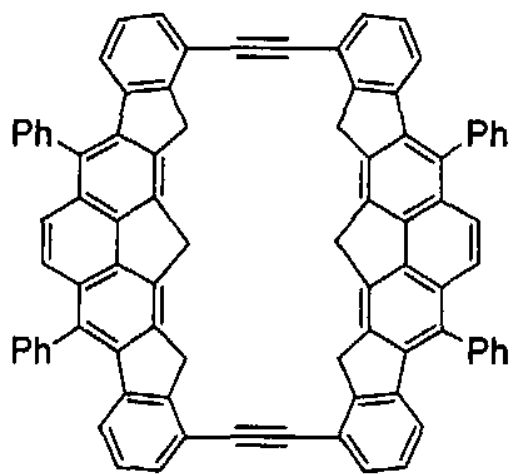

12

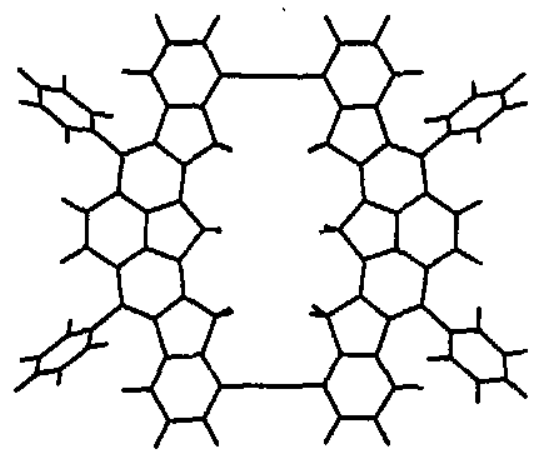

12 MM2-optimized, top view

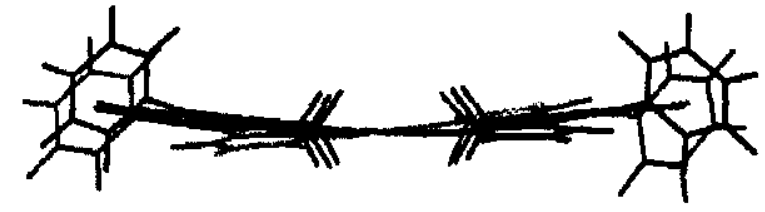

12 MM2-optimized, side view

Figure 2 Structures of compounds 10, 11, and 12

The positions of the two bromo substituents in 10 play an important role in the design of the synthetic route for the macrocyclic acetylene 12 . The two bromo substituents, both attached on the C-1 position of the two fluorene subunits in $\mathbf{1 0}$, provided handles for the Sonogashira reactions and also insured the parallel orientation of 
the two acetylenic groups of diacetylene 11. In the Sonogashira cross-coupling reactions between 10 and 11, following the first Sonogashira reaction, the remaining acetylene and the second aryl bromide could undergo an intramolecular Sonogashira reaction to form macrocyclic acetylene 12. Because of the rigid carbon frameworks in 10 and 11 and the optimal positions of the two bromo substituents in $\mathbf{1 0}$ and the two acetylenic groups in 11, it is highly likely that after the first Sonogashira reaction, the remaining acetylenic group and the second aryl bromide would undergo an intramolecular Sonogashira reaction to form macrocyclic acetylene 12 . In order to produce dibromide 10 , it is necessary to prepare diacetylene 13 bearing a bromo substituent for condensations with diketone 1 to obtain the important precursor propargylic diol 14 (Scheme 7).

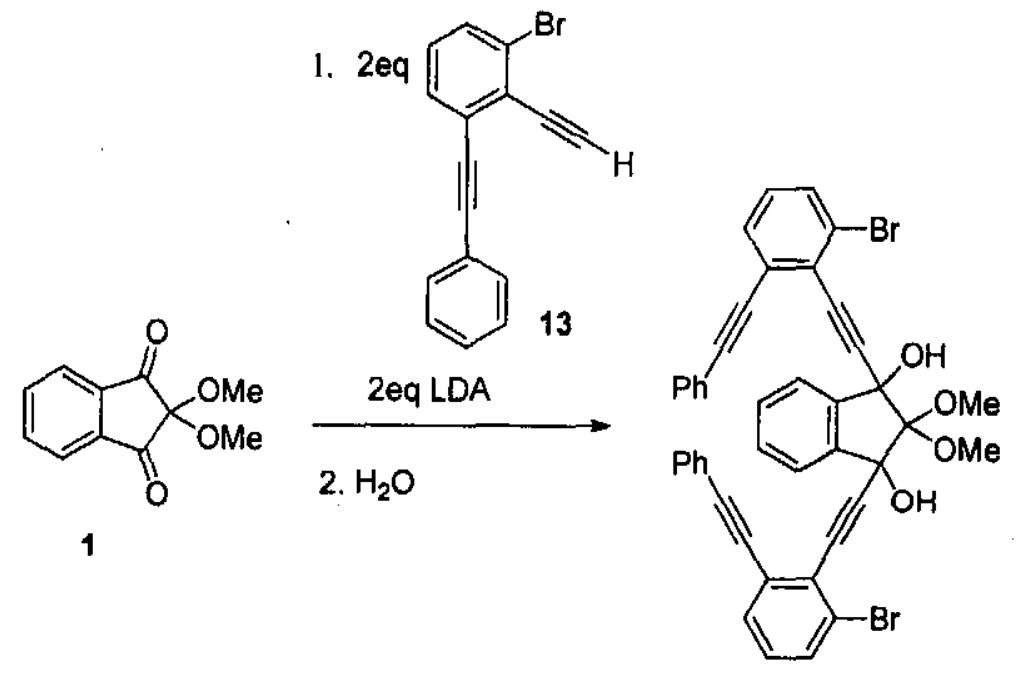

14

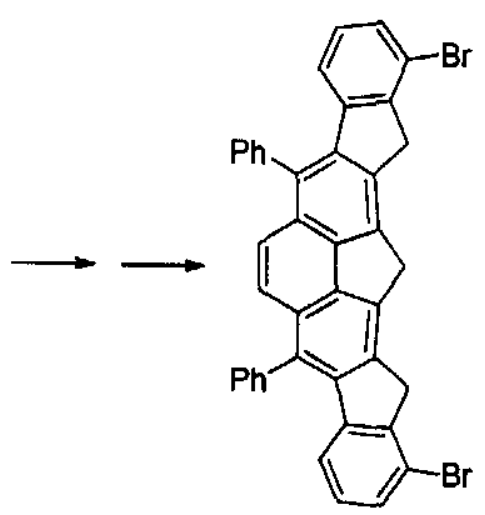

10

Scheme 7 


\section{Results and Discussion}

3.1 Synthesis of 2,2-dimethoxy-1,3-indandione (1)

The preparation of the 2,2-dimethoxy-1,3-indandione (1) was conducted according to a reported procedure. ${ }^{20}$ Treatment of ninhydrin (2,2-dihydroxyindane-1,3-dione) with silver(I) oxide, and iodomethane provided diketone 1 in $90 \%$ isolated yield (Scheme 8).<smiles>O=C1c2ccccc2C(=O)C1(O)O</smiles>

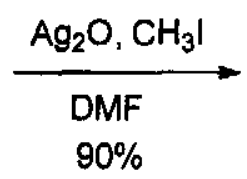<smiles>COC1(OC)C(=O)c2ccccc2C1=O</smiles>

1

\section{Scheme 8}

3.2 Synthesis of 1-bromo-2-ethynyl-3-(2-phenylethynyl)benzene (13)

The synthetic procedure for $\mathbf{1 3}$ was initially developed by Changfeng Huang of our research group (Scheme 9). Treatment of the commercially available 1,3-dibromobenzene (15) with lithium diisopropylamide (LDA) and iodine produced 1,3-dibromo-2iodobenzene (16) in $72 \%$ yield. ${ }^{21}$ Then a Pd-catalyzed cross-coupling reaction between 16 and (trimethylsilyl)acetylene furnished 1,3-dibromo-2-[2(trimethylsilyl)ethynyi]benzene (17) in $80 \%$ yield. Reaction of 17 with $n$-butyllithium and iodine produced 1-bromo-3-iodio-2-[2-(trimethylsilyl)ethynyl]benzene (18) in 94\% yield. A subsequent Pd-catalyzed cross-coupling reaction between 18 and 
phenylacetylene provided 1-bromo-2-[2-(trimethylsilyl)ethynyl]-3-(2-

phenylethynyl)benzene (19) in $78 \%$ yield. Desilylation of 19 then produced diacetylene 13 in $96 \%$ yield.
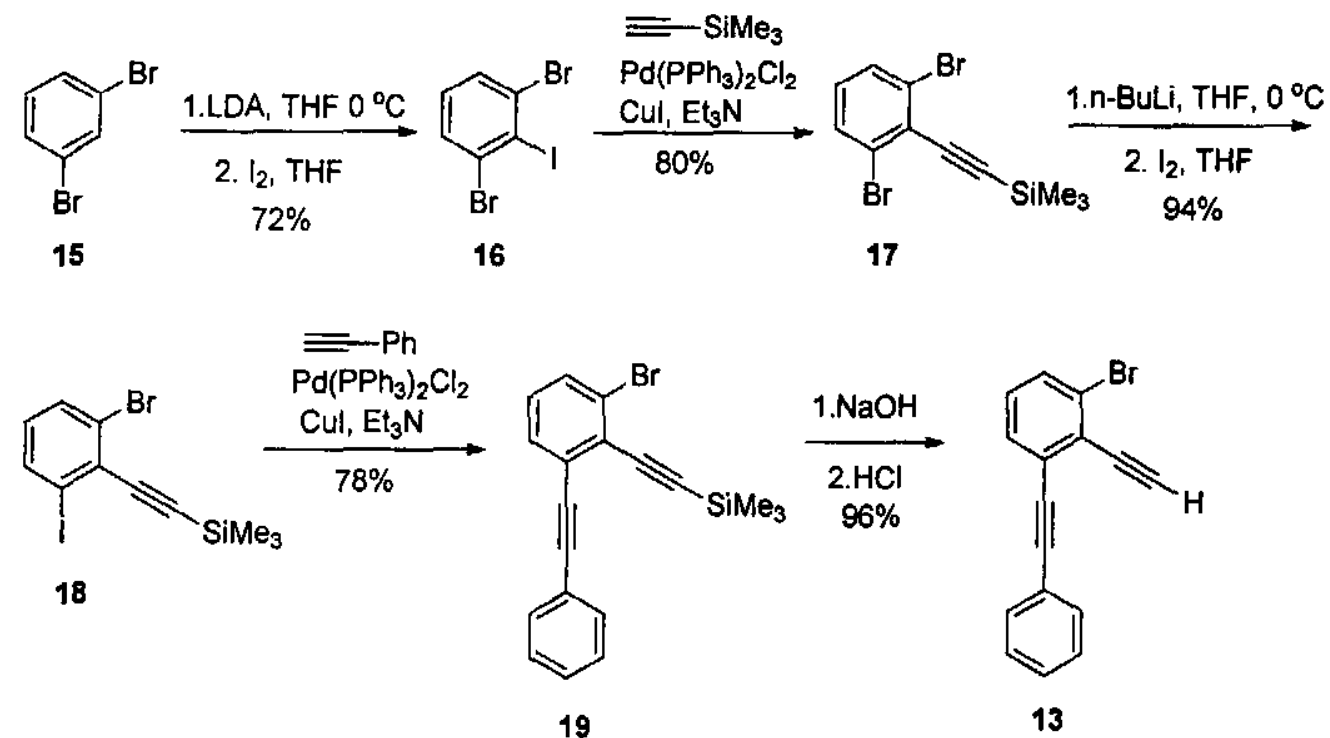

Scheme 9

3.3 Schmittel cyclization reaction ${ }^{22}$

Condensation of diketone 1 with the lithium acetylide of 13a, obtained by lithiation of 1-bromo-2-ethynyl-3-[2-phenylethynyl]benzene (13) with LDA, followed by hydrolytic workup produced the trans propargylic diol 20a in 50\% yield, monopropargylic alcohol 20b in $47 \%$ yield, and a small amount of the cis propargylic diol 20c (Scheme 10). 


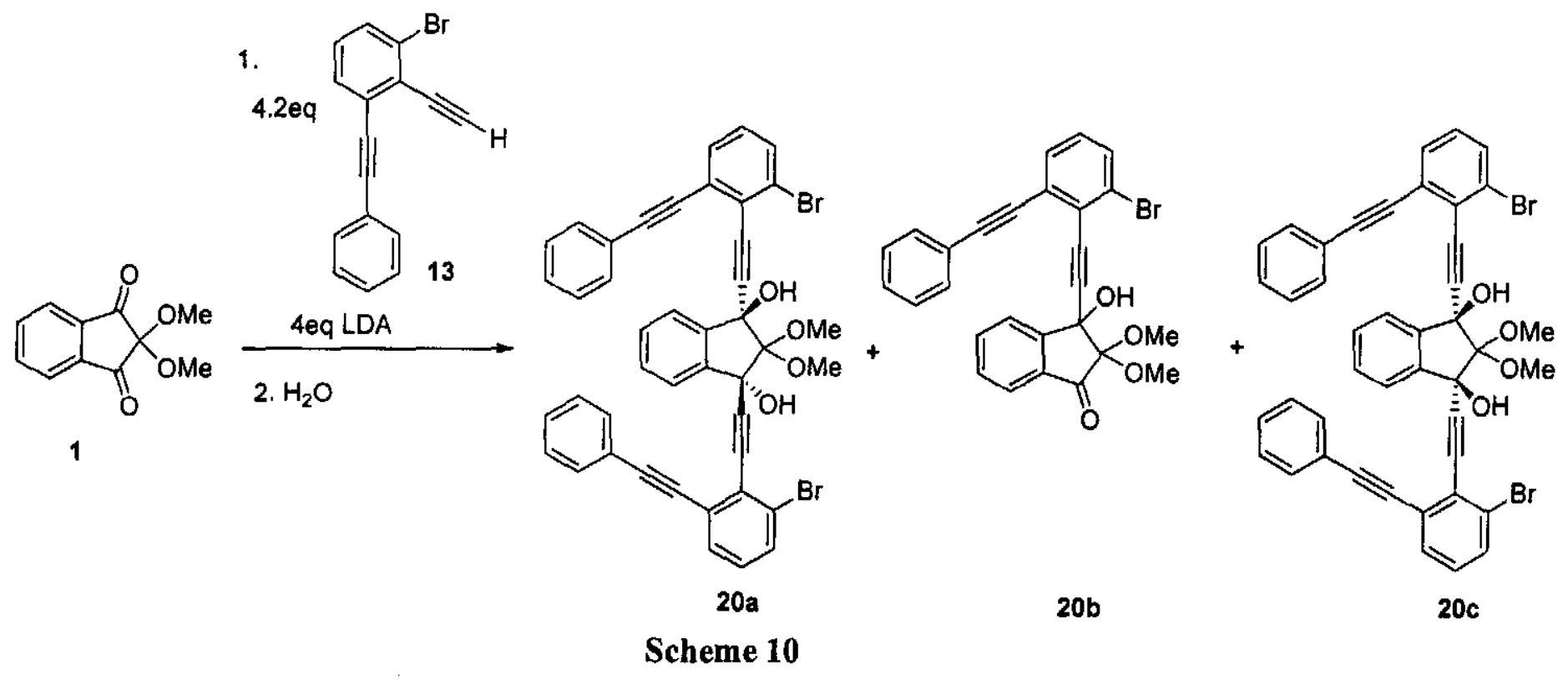

In the reported synthetic route the lithium acetylide used in the condensation with diketone 1 was prepared by the lithiation of 1-(2-ethynylphenyl)-2-phenylethyne (2) with $n$-butyllithium (Scheme 6). ${ }^{19}$ However, using $n$-butyllithium for the lithiation of 1-bromo2-ethynyl-3-(2-phenylethynyl)benzene (13) was not successful because the undesired metal-bromine exchange reaction competes with lithiation. The ${ }^{1} \mathrm{H}$ NMR spectra of the products after hydrolytic workup indicated the formation of recovered 1-bromo-2ethynyl-3-(2-phenylethynyl)benzene (13) and debrominated 1-(2-ethynylphenyl)-2phenylethyne (2) (Scheme 11). In order to prevent the formation of the debrominated adduct, lithium diisopropylamide was used in the condensation reaction and reaction time was carefully monitored and controlled. Using such reaction condition, the formation of the debrominated adduct was avoided. 


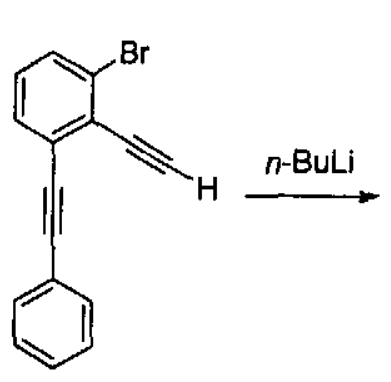

13

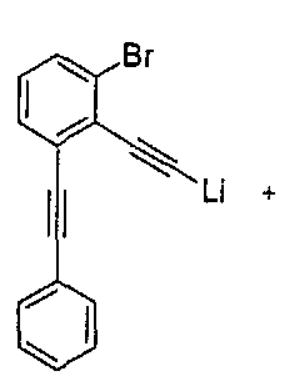

$13 a$

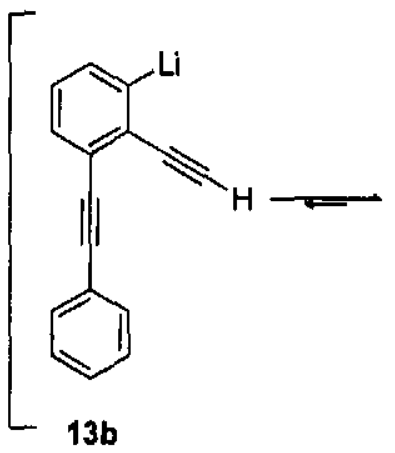

(13c)

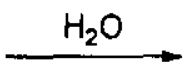

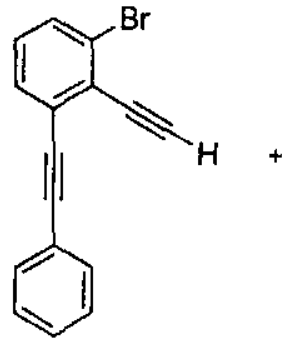

13<smiles>C#Cc1ccccc1C#Cc1ccccc1</smiles>

2

\section{Scheme 11}

The characteristic ${ }^{1} \mathrm{H}$ NMR signals of the reported trans-propargylic diol 3a was used to identify the corresponding trans propargylic diol 20a possessing two bromo substituents. Both trans propargylic diols 3a and 20a exhibit ${ }^{1} \mathrm{H}$ NMR signals at $\delta 7.70$ as doublet of doublet arising from the aromatic portion of indane moieties. A singlet at $\delta$ 3.84 arising from the two methoxy groups of $20 \mathrm{a}$, and a singlet at $\delta 3.83$ also arising from the two methoxy groups of 3 a were observed. In addition a triplet signal at $\delta 7.13$ can be attributed to the aromatic hydrogens meta to the bromo substituents in $20 \mathrm{a}$. The HRMS of 20a is also consistent with the assigned structure (Figure 3). 


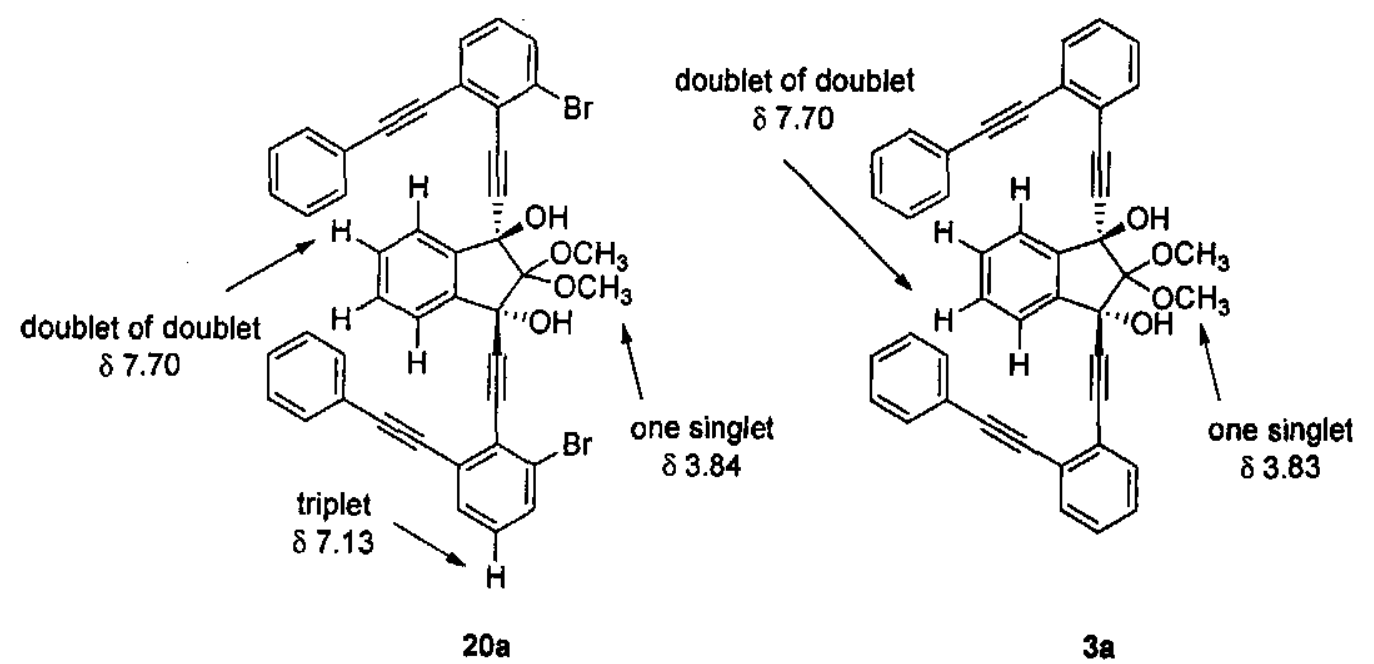

Figure 3 Structures of compounds 20a and 3a and the characteristic ${ }^{1} \mathrm{H}$ NMR signals

Treament of propargylic diol 20a with thionyl chloride promoted a sequence of reactions with the initial formation of the chlorosulfite $\mathbf{2 1}$ followed with two $\mathrm{S}_{\mathrm{N}} \mathrm{i}^{1}$ reactions ${ }^{23}$ to generate in situ the chlorinated benzoenyne-allene 22 (Scheme 12). Then the following Schmittel cyclization reactions produced the Diels-Alder adduct 23.

Dichloride $\mathbf{2 3}$ is prone to hydrolysis, and produced, after column chromatography over silica gel, a small amount of diol 24 as a mixture of the cis-isomer 24a and trans-isomer $24 \mathbf{b}$. 


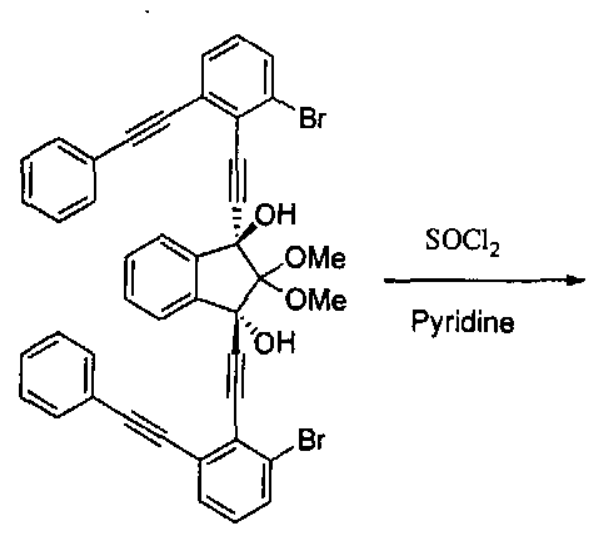

20a
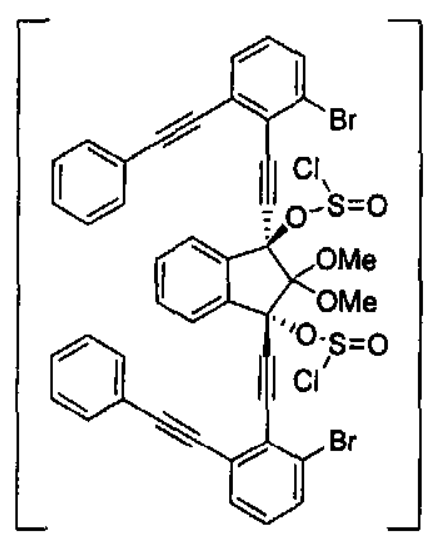

21

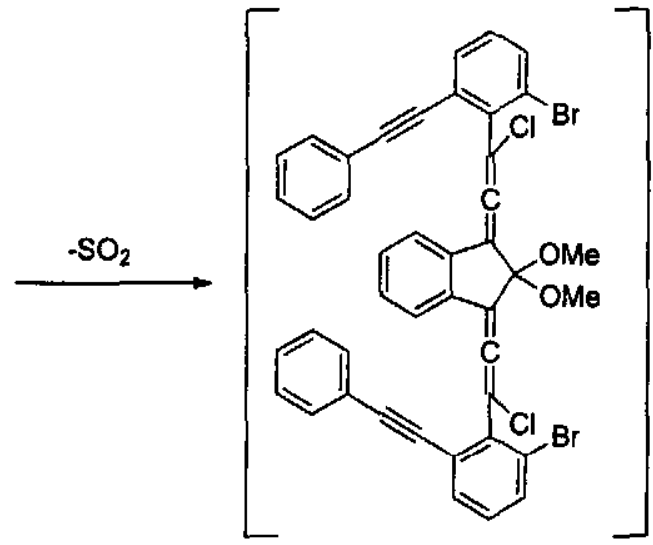

22

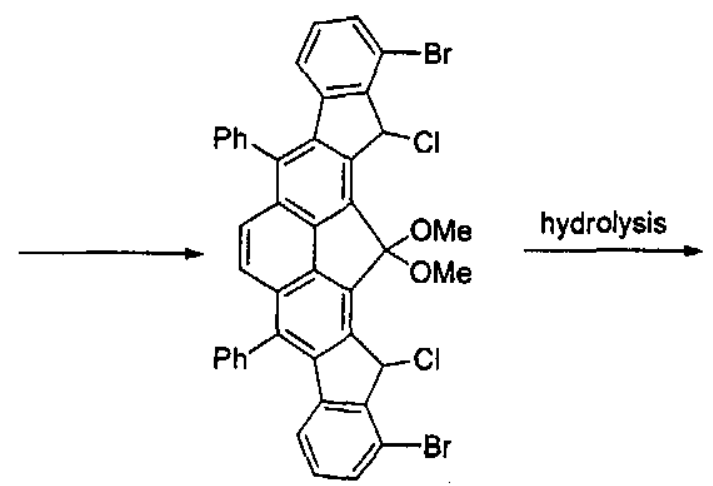

23<smiles></smiles>

24

Scheme 12

Due to the orientation of the phenyl substituents in $24 \mathbf{a}$ and $24 \mathbf{b}$, the neighboring aromatic hydrogens on the benzene rings bearing a bromo substituent are shielded magnetically. As a result, the proton NMR signals of these hydrogen atoms are shifted upfield to $\delta 6.50$ (doublet, 24a) and $\delta 6.52$ (doublet, 24b), respectively. In addition, the hydrogens on the five-membered rings of the two fluorenyl subunits exhibit ${ }^{1} \mathrm{H}$ NMR signals at $\delta 6.30$ (singlet, 24a) and $\delta 6.32$ (singlet, 24b), respectively. Furthermore, two singlets at $\delta 3.38$ and $\delta 3.36$ arising from the two methoxy groups of $24 a$, and a singlet at $\delta 3.24$ arising from the two methoxy groups of $24 \mathbf{b}$ were observed (Figure 4). The HRMS of the mixture is also consistent with the elemental composition of assigned structures. 


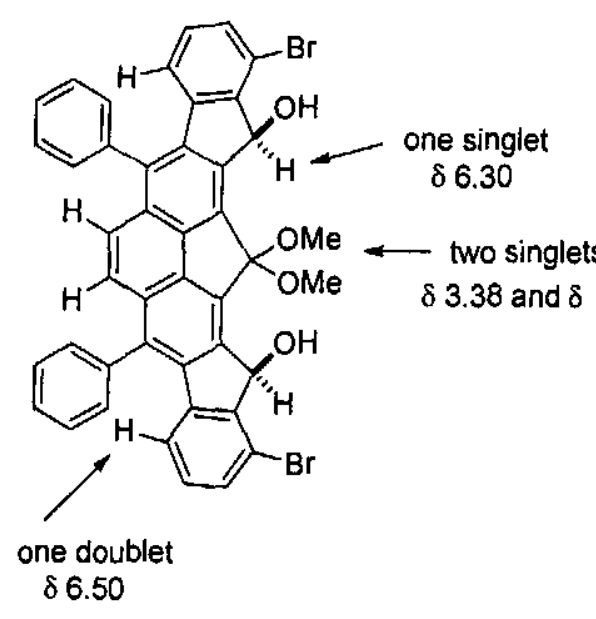

$24 a$

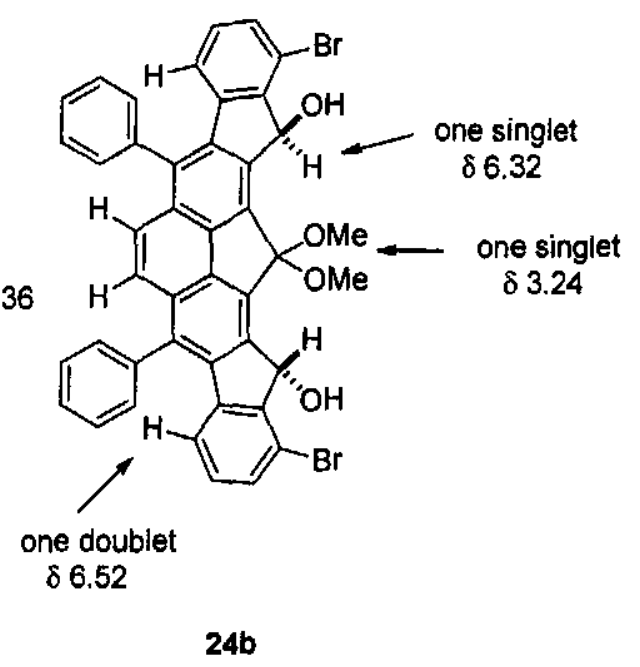

Figure 4 Structures of compounds $24 \mathrm{a}$ and $24 \mathrm{~b}$ and the characteristic ${ }^{1} \mathrm{H}$ NMR signals

\section{Conclusions}

Two diindeno-fused $4 H$-cyclopenta[def]phenanthrene derivatives containing two bromo substituents (24a and $24 b$ ) were synthesized. The synthetic route used an excess of 1-bromo-2-ethynyl-3-(2-phenylethynyl)benzene (13) for condensation with 2,2dimethoxy-1,3-indandione (1) to prepare the corresponding diols for the Schmittel cyclization reaction, leading to a novel molecular carbon framework of diindeno-fused $4 H$-cyclopenta[def]phenanthrene bearing two bromo substituents as handles for further Sonogashira coupling reactions. Such a synthetic sequence could provide a new synthetic pathway for the construction of macrocyclic acetylenes. 


\section{Part II}

\section{EXPERIMENTAL SECTION}

Glassware used for all reactions were dried in an oven $\left(110^{\circ} \mathrm{C}\right)$ for at least 8 hours. All reactions were carried under a nitrogen atmosphere. Dichloromethane, diethyl ether, ethyl acetate, hexanes, and methanol were reagent grade and used as received. All other liquid reagent and solid chemicals were purchased from chemical suppliers and were used as received. Anhydrous tetrahydrofuran $(\geq 99.9 \%)$, anhydrous diethyl ether $(\geq 99.7 \%), N, N$ dimethylformamide (DMF) (anhydrous, 99.8\%), Copper(I) iodide, iodomethane, lithium diisopropylamide solution (2.0 M) in THF/n-heptane/ethylbenzene, $n$-butyllithium (1.6 M) in hexanes, pyridine (anhydrous), and thionyl chloride were purchased from Sigma-Aldrich. Ninhydrin, triethylamine (99.7\%), triphenylphosphine, phenylacetylene, and iodine were purchased from Acros Organics. Silver (I) oxide was purchased from Strem Chemicals, Inc. Bis(triphenylphosphine)palladium(II) dichloride, and trimethylsilylacetylene were purchased from Oakwood Products, Inc. Silica gel for flash column chromatography was purchased from Dynamic Adsorbents. ${ }^{1} \mathrm{H}$ NMR (600 MHz) and ${ }^{13} \mathrm{C}$ NMR (150 MHz) spectra were recorded in $\mathrm{CDCl}_{3}$ using $\mathrm{CHCl}_{3}\left({ }^{1} \mathrm{H} \delta\right.$ 7.26) and $\mathrm{CDCl}_{3}\left({ }^{13} \mathrm{C} \delta 77.0\right)$ as internal standards. 


\section{1,3-dibromo-2-iodobenzene $(16)^{21}$}

A solution of $2.0 \mathrm{~mL}$ of 1,3 -dibromobenzene $(15)(3.9 \mathrm{~g}, 16.5 \mathrm{mmol})$ in $50 \mathrm{~mL}$ of anhydrous THF under a nitrogen atmosphere was cooled to $-78^{\circ} \mathrm{C}$. After $15 \mathrm{~min}$ of stirring, $25 \mathrm{~mL}$ of a 2.0 M solution of LDA $(50 \mathrm{mmol})$ was added dropwise at $-78^{\circ} \mathrm{C}$. After 2 hours of stirring at $78^{\circ} \mathrm{C}$, a solution of $6.3 \mathrm{~g}$ of iodine $(24.8 \mathrm{mmol})$ in $20 \mathrm{~mL}$ of anhydrous THF was introduced dropwise via cannula, and the reaction mixture was allowed to warm to room temperature. After overnight, $30 \mathrm{~mL}$ of water was introduced, and the reaction mixture was then extracted with $50 \mathrm{~mL}$ of diethyl ether. The organic layer was washed with brine and water, dried with sodium sulfate, and concentrated. The residue was purified by flash column chromatography (silica gel/ hexanes) to produce $4.16 \mathrm{~g}$ of $16(11.5 \mathrm{mmol}, 72 \%)$ as a white solid: ${ }^{1} \mathrm{H}$ NMR $\left(\mathrm{CDCl}_{3}, 600 \mathrm{MHz}\right) \delta 7.55(2 \mathrm{H}, \mathrm{d}, J=7.8 \mathrm{~Hz}), 7.07(1 \mathrm{H}, \mathrm{t}, J=8.4 \mathrm{~Hz}) ;{ }^{13} \mathrm{C} \mathrm{NMR}\left(\mathrm{CDCl}_{3}\right.$, $150 \mathrm{MHz}) \delta 131.3,131.1,130.3,109.3$.

\section{1,3-dibromo-2-[2-(trimethylsilyl)ethynyl]benzene (17)}

A mixture of 1,3-dibromo-2-iodobenzene (16) (3.39 g, $9.36 \mathrm{mmol})$, bis(triphenylphosphine)palladium(II) dichloride $(0.329 \mathrm{~g}, 0.468 \mathrm{mmol})$, copper(I) iodide $(0.178 \mathrm{~g}, 0.936 \mathrm{mmol})$, and triphenylphosphine $(49 \mathrm{mg}, 0.187 \mathrm{mmol})$ was dissolved in $30 \mathrm{~mL}$ of triethylamine and flushed with nitrogen. After $15 \mathrm{~min}$ of stirring, $2.45 \mathrm{~mL}$ of (trimethylsilyl)acetylene $(1.84 \mathrm{~g}, 18.7 \mathrm{mmol})$ was introduced dropwise. Then the reaction mixture was heated to reflux at $69^{\circ} \mathrm{C}$. After 3 hours of reflux, an additional $2.45 \mathrm{~mL}$ of (trimethylsilyl)acetylene ( $1.84 \mathrm{~g}, 18.7 \mathrm{mmol}$ ) was added dropwise. After an additional 3 hours 
of reflux at $69^{\circ} \mathrm{C}, 50 \mathrm{~mL}$ of water was added, and the reaction mixture was extracted with 50 $\mathrm{mL}$ of diethyl ether. The organic layer was filtered to remove precipitates, and the filtrate was dried with sodium sulfate and concentrated. The residue was purified by flash column chromatography (silica gel/30\% ethyl acetate in hexanes) to produce $2.49 \mathrm{~g}$ of $17(7.5 \mathrm{mmol}$, $80 \%)$ as a light yellow oil: ${ }^{1} \mathrm{H} N M R\left(\mathrm{CDCl}_{3}, 600 \mathrm{MHz}\right) \delta 7.52(2 \mathrm{H}, \mathrm{d}, J=7.8 \mathrm{~Hz}), 6.99(1 \mathrm{H}$, $\mathrm{t}, J=8.4 \mathrm{~Hz}), 0.30(9 \mathrm{H}, \mathrm{s}) ;{ }^{13} \mathrm{C} \mathrm{NMR}\left(\mathrm{CDCl}_{3}, 150 \mathrm{MHz}\right) \delta 131.2,129.7,127.0,126.6,105.4$, $101.7,-0.27$.

\section{1-bromo-3-iodio-2-[2-(trimethylsilyl)ethynyl]benzene (18)}

A solution of $1.44 \mathrm{~g}$ of 1,3-dibromo-2-[2-(trimethylsilyl)ethynyl]benzene (17) $(4.3 \mathrm{mmol})$ in $30 \mathrm{~mL}$ of anhydrous diethyl ether under a nitrogen atmosphere was cooled to $-78^{\circ} \mathrm{C}$. After 15 min of stirring, $4.1 \mathrm{~mL}$ of a $1.6 \mathrm{M}$ solution of $n$-butyllithium $(6.5 \mathrm{mmol})$ was introduced dropwise at $-78^{\circ} \mathrm{C}$. After 2 hours of stirring at $-78^{\circ} \mathrm{C}$, a solution of $1.65 \mathrm{~g}$ of iodine $(6.5$ $\mathrm{mmol}$ ) in $20 \mathrm{~mL}$ of anhydrous diethyl ether was introduced dropwise via cannula, and the reaction mixture was allowed to warm to room temperature. After overnight, $50 \mathrm{~mL}$ of water was introduced, and the reaction mixture was extracted with $50 \mathrm{~mL}$ of diethyl ether. The organic layer was washed with brine and water, dried with sodium sulfate, and concentrated. The residue was purified by flash column chromatography (silica gel $/ 30 \%$ ethyl acetate in hexanes) to produce $1.54 \mathrm{~g}$ of $18(4.0 \mathrm{mmol}, 94 \%)$ as a light-yellow oil: ${ }^{1} \mathrm{H} \mathrm{NMR}\left(\mathrm{CDCl}_{3}\right.$, $600 \mathrm{MHz}) \delta 7.76(1 \mathrm{H}, \mathrm{dd}, J=7.8,1.2 \mathrm{~Hz}), 7.54(1 \mathrm{H}, \mathrm{dd}, J=7.8,1.2 \mathrm{~Hz}), 6.81(1 \mathrm{H}, \mathrm{t}, J=$ $8.4 \mathrm{~Hz}), 0.31(9 \mathrm{H}, \mathrm{s}) ;{ }^{13} \mathrm{C} \mathrm{NMR}\left(\mathrm{CDCl}_{3}, 150 \mathrm{MHz}\right) \delta 137.6,132.0,130.9,130.0,125.1,105.3$, $104.3,101.6,-0.29$. 


\section{1-bromo-2-[2-(trimethylsilyl)ethynyl]-3-(2-phenylethynyl)benzene (19)}

A mixture of 1-bromo-3-iodio-2-[2-(trimethylsilyl)ethynyl]benzene (18) $(1.35 \mathrm{~g}, 3.6 \mathrm{mmol})$, bis(triphenylphosphine)palladium(II) dichloride $(0.075 \mathrm{~g}, 0.10 \mathrm{mmol})$, and copper(I) iodide $(0.034 \mathrm{~g}, 0.18 \mathrm{mmol})$ was dissolved in $30 \mathrm{~mL}$ of triethylamine and flushed with nitrogen. After $15 \mathrm{~min}$ of stirring, $0.46 \mathrm{~mL}$ of phenylacetylene was added at room temperature. After overnight, $50 \mathrm{~mL}$ of water was introduced, and the reaction mixture was extracted with $50 \mathrm{~mL}$ of diethyl ether. The organic layer was filtered to remove precipitates, and the filtrate was dried over sodium sulfate and concentrated. The residue was purified by flash column chromatography (silica gel $/ 30 \%$ ethyl acetate in hexanes) to produce $0.99 \mathrm{~g}$ of $19(2.8 \mathrm{mmol}$,

$78 \%)$ as a yellow oil: ${ }^{1} \mathrm{H}$ NMR $\left(\mathrm{CDCl}_{3}, 600 \mathrm{MHz}\right) \delta 7.58-7.56(2 \mathrm{H}, \mathrm{m}), 7.53(1 \mathrm{H}, \mathrm{dd}, J=7.8$, $1.2 \mathrm{~Hz}), 7.46(1 \mathrm{H}, \mathrm{dd}, J=7.8,1.2 \mathrm{~Hz}), 7.385-7.34(3 \mathrm{H}, \mathrm{m}), 7.12(1 \mathrm{H}, \mathrm{t}, J=8.4 \mathrm{~Hz}), 0.29(9$ $\mathrm{H}, \mathrm{s}) ;{ }^{13} \mathrm{C} \mathrm{NMR}\left(\mathrm{CDCl}_{3}, 150 \mathrm{MHz}\right) \delta 132.0,131.7,130.4,128.7,128.6,128.4,127.9,127.4$, $125.9,122.9,104.3,101.7,94.2,87.7,-0.11$.

\section{1-bromo-2-ethynyl-3-(2-phenylethynyl)benzene (13)}

To a solution of $0.41 \mathrm{~g}$ of 1-bromo-2-[2-(trimethylsilyl)ethynyl]-3-(2-phenylethynyl)benzene (19) $(1.15 \mathrm{mmol})$ dissolved in $30 \mathrm{~mL}$ of diethyl ether and $30 \mathrm{~mL}$ of methanol was added 20 $\mathrm{mL}$ of a $10 \%$ sodium hydroxide solution. The reaction mixture was stirred for 3 hours at room temperature, and then extracted with $50 \mathrm{~mL}$ of diethyl ether. The organic layer was washed with $25 \mathrm{~mL}$ of a $2.0 \mathrm{M}$ solution of hydrochloric acid and $50 \mathrm{~mL}$ of water, dried over sodium 
sulfate, and concentrated. The residue was purified by flash column chromatography (silica gel/ pure hexanes) to produce $0.31 \mathrm{~g}$ of $\mathbf{1 3}(1.10 \mathrm{mmol}, 96 \%)$ as a dark-yellow oil: ${ }^{1} \mathrm{H}$ NMR $\left(\mathrm{CDCl}_{3}, 600 \mathrm{MHz}\right) \delta 7.58-7.55(3 \mathrm{H}, \mathrm{m}), \delta 7.49(1 \mathrm{H}, \mathrm{dd}, J=7.8,1.2 \mathrm{~Hz}), 7.37-3.36(3 \mathrm{H}, \mathrm{m})$,

$7.17(1 \mathrm{H}, \mathrm{t}, J=8.4 \mathrm{~Hz}), 3.68(1 \mathrm{H}, \mathrm{s}) ;{ }^{13} \mathrm{C} \mathrm{NMR}\left(\mathrm{CDCl}_{3}, 150 \mathrm{MHz}\right) \delta 132.0,131.8,130.5$, $129.1,128.8,128.5,128.4,126.3,125.9,122.7,94.4,87.3,86.0,80.8$.

\section{propargylic diols 20a, 20c, and propargylic mono-ol 20b}

A solution of $0.67 \mathrm{~g}$ of 1-bromo-2-ethynyl-3-(2-phenylethynyl)benzene (13) (2.4 mmol) in 20 $\mathrm{mL}$ of anhydrous THF under a nitrogen atmosphere was cooled to $0^{\circ} \mathrm{C}$. After $15 \mathrm{~min}$ of stirring, $1.14 \mathrm{~mL}$ of a $2.0 \mathrm{M}$ solution of lithium diisopropylamide (LDA) $(2.28 \mathrm{mmol})$ was added dropwise at $0{ }^{\circ} \mathrm{C}$. After $30 \mathrm{~min}$ of stirring at $0^{\circ} \mathrm{C}$, a solution of $0.67 \mathrm{~g}$ of diketone 1 $(0.57 \mathrm{mmol})$ in $20 \mathrm{~mL}$ of anhydrous THF was introduced dropwise via cannula, and the reaction mixture was allowed to warm to room temperature. After 1 hour of stirring, $20 \mathrm{~mL}$ of water was added and the reaction mixture was extracted with $40 \mathrm{~mL}$ of diethyl ether. The organic layer was separated, dried over sodium sulfate, and concentrated. The residue was purified by flash column chromatography (silica gel/20\% ethyl acetate in hexanes) to produce $0.92 \mathrm{~g}$ of $20 \mathrm{a}(1.2 \mathrm{mmol}, 50 \%)$ as a yellow solid and $0.55 \mathrm{~g}$ of $20 \mathrm{~b}(1.13 \mathrm{mmol}, 47 \%)$ as yellow solid. 20a: ${ }^{1} \mathrm{H}$ NMR $\left(\mathrm{CDCl}_{3}, 600 \mathrm{MHz}\right) \delta 7.70(2 \mathrm{H}, \mathrm{dd}, J=5.4,3.0 \mathrm{~Hz}), 7.53(2 \mathrm{H}$, dd, $J=7.8,1.2 \mathrm{~Hz}), 7.50-7.46(6 \mathrm{H}, \mathrm{m}), 7.35-7.29(6 \mathrm{H}, \mathrm{m}), 7.21(2 \mathrm{H}, \mathrm{dd}, J=6.0,3.0 \mathrm{~Hz}), 7.13(2$ $\mathrm{H}, \mathrm{t}, J=7.8 \mathrm{~Hz}), 3.84(6 \mathrm{H}, \mathrm{s}) ;{ }^{13} \mathrm{C} \mathrm{NMR}\left(\mathrm{CDCl}_{3}, 150 \mathrm{MHz}\right) \delta 142.0,132.0,131.9,130.7$, $129.8,129.0,128.6,128.3,128.2,126.5,126.0,124.5,122.7,109.8,96.4,94.2,87.4,85.4$, 77.3, 53.4; HRMS calcd for $\mathrm{C}_{43} \mathrm{H}_{28} \mathrm{Br}_{2} \mathrm{O}_{4} \mathrm{Na}\left(\mathrm{MNa}^{+}\right)$791.0226, found 791.0236; 
20b: ${ }^{1} \mathrm{H}$ NMR $\left(\mathrm{CDCl}_{3}, 600 \mathrm{MHz}\right) \delta 7.89(1 \mathrm{H}, \mathrm{d}, J=8.4 \mathrm{~Hz}), 7.73(1 \mathrm{H}, \mathrm{d}, J=7.2 \mathrm{~Hz}), 7.57-$ 7.34(9 H, m), $7.14(1 \mathrm{H}, \mathrm{t}, J=8.4 \mathrm{~Hz}), 3.62(3 \mathrm{H}, \mathrm{s}) 3.59(3 \mathrm{H}, \mathrm{s}) ;{ }^{13} \mathrm{C} \mathrm{NMR}\left(\mathrm{CDCl}_{3}, 150 \mathrm{MHz}\right)$ $\delta 152.6,136.2,131.9,131.8,131.7,131.6,131.4,130.6,129.9,129.1,128.6,128.2,128.2$, $128.2,128.1,127.9,126.0,125.1,124.0,122.5,102.0,94.0,87.1,86.9,74.2,51.9,51.7$; HRMS calcd for $\mathrm{C}_{27} \mathrm{H}_{19} \mathrm{BrO}_{4} \mathrm{Na}\left(\mathrm{MNa}^{+}\right)$509.0359, found 509.0367.

\section{diols 24a and 24b}

A solution of $0.568 \mathrm{~g}$ of propargylic diol (20a) $(0.074 \mathrm{mmol})$ in $50 \mathrm{~mL}$ of anhydrous THF under a nitrogen atmosphere was cooled to $0^{\circ} \mathrm{C}$. After $15 \mathrm{~min}$ of stirring, a mixture of 0.03 $\mathrm{mL}$ of thionyl chloride $(0.44 \mathrm{mmol})$ and $0.08 \mathrm{~mL}$ of anhydrous pyridine $(1.0 \mathrm{mmol})$ in $20 \mathrm{~mL}$ of anhydrous THF was added via cannula. Then the reaction mixture was allowed to warm to room temperature. After 1 hour, $20 \mathrm{~mL}$ of water and $30 \mathrm{~mL}$ methylene chloride were added. The organic layer was separated, dried over sodium sulfate, and concentrated. The residue was purified by flash column chromatography (silica gel $/ 20 \%$ ethyl acetate in hexanes) to produce little amounts of $24 \mathrm{a}$ and $\mathbf{2 4 b}$ as dark red solid. Nonaromatic protons were assigned to 24a and 24b as indicated earlier in the section of Results and Discussion. 24a: ${ }^{1} \mathrm{H} N M R\left(\mathrm{CDCl}_{3}, 600\right.$ MHz) $\delta 6.50(2 \mathrm{H}, \mathrm{d}), 6.30(2 \mathrm{H}, \mathrm{s}), 3.38(3 \mathrm{H}, \mathrm{s}), 3.36(3 \mathrm{H}, \mathrm{s}) ; 24 \mathrm{~b}:{ }^{1} \mathrm{H}$ NMR $\left(\mathrm{CDCl}_{3}, 600 \mathrm{MHz}\right)$ $\delta 6.52(2 \mathrm{H}, \mathrm{d}), 6.32(2 \mathrm{H}, \mathrm{s}), 3.34(6 \mathrm{H}, \mathrm{s})$; HRMS calcd for $\mathrm{C}_{43} \mathrm{H}_{29} \mathrm{Br}_{2} \mathrm{O}_{4}\left(\mathrm{MH}^{+}\right)$767.0427, found 767.0440 . 


\section{REFERENCES}

1. Moore, J. S. Acc. Chem. Res. 1997, 30, 402.

2. Faust, R. Angew. Chem., Int. Ed. 1998, 37, 2825.

3. Haley, M. M.; Pak, J. J.; Brand, S. C. Top. Curr. Chem. 1999, $201,82$.

4. Youngs, W. J.; Tessier, C. A.; Bradshaw, J. D. Chem. Rev. 1999, 99, 3153.

5. Grave, C.; Schlu"ter, A. D. Eur. J. Org. Chem. 2002, 3075.

6. Zaho, D.; Moore, J. S. Chem. Commun. 2003, 7, 807.

7. Tobe, Y.; Tahara, K. Chem. Rev. 2006, 106, 5274

8. Wong, H. N. C.; Garratt, P. J.; Sondheimer, F. J. Am. Chem. Soc.1974, 96, 5604.

9. Huang, N. Z.; Sondheimer, F. Acc. Chem. Res. 1982, 15, 96

10. Wong, H. N. C. Acc. Chem. Res. 1989, 22, 145.

11. Norinder,U.; Wennerström, O. Tetrahedron Lett. 1983, 24, 5411.

12. McNulty, J.; Das, P. Eur. J. Org. Chem. 2009, 4031

13. Sonogashira, K.;Tohda, Y.; Hagihara, N. Tetrahedron Lett. 1975, 16, 4467.

14. Moore, J. S.; Zhang, J. Angew. Chem. 1992, 104, 873

15. Kawase, T.;Seirai, Y.; Darabi, H. R.; Oda, M.; Sarakai,Y.; Tashiro, K. Angew. Chem., Int. Ed. 2003, 42, 1621.

16. Nishinaga, T.; Kawamura, T.; Komatsu, K. J. Org. Chem. 1997, 62, 5354.

17. Kawase, T.; Kurata, H. Chem. Rev. 2006, 106, 5250

18. Haley, M.M.; Johnson II, C. A.;Spitler, E.L. Chem. Rev. 2006, 106, 5344

19. Han, X.Q.; Zhang, Y.H.; Wang, K.K. J. Org. Chem. 2005, 70, 2406.

20. Kuhn, R.; Trischmann, H. Chem. Ber. 1961, 94, 2258. 
21. Schlosser, M.; Leroux, F. Angew. Chem. Int. Ed. 2002, 41, No.22, 4272.

22. Schmittel, M.; Strittmatter, M. Tetrahedron Lett. 1998, 54, 13751.

23. Jacobs, T. L.; Fenton, D. M. J. Org. Chem. 1965, 30, 1808. 
APPENDIX

$-25$. 


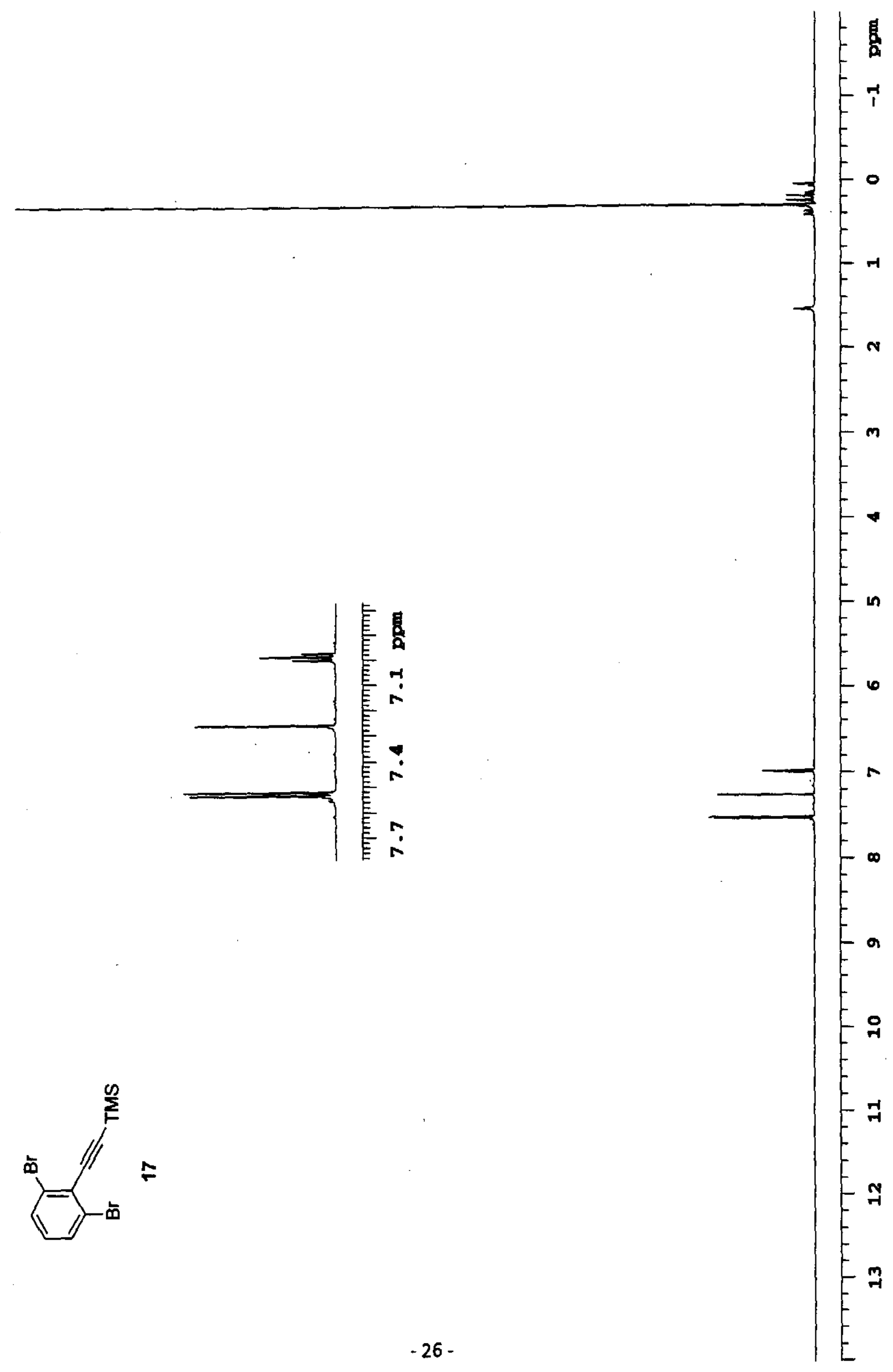




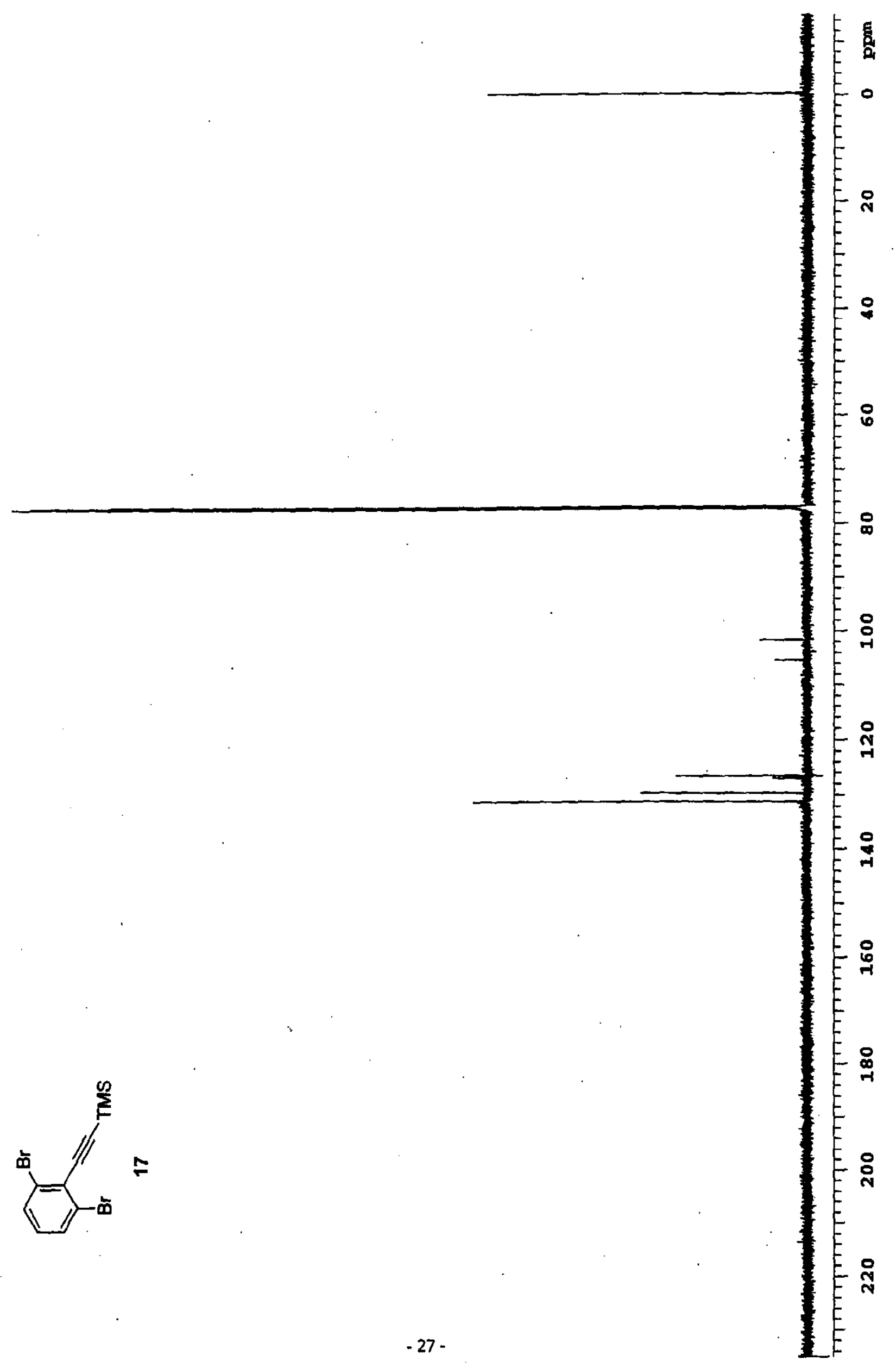




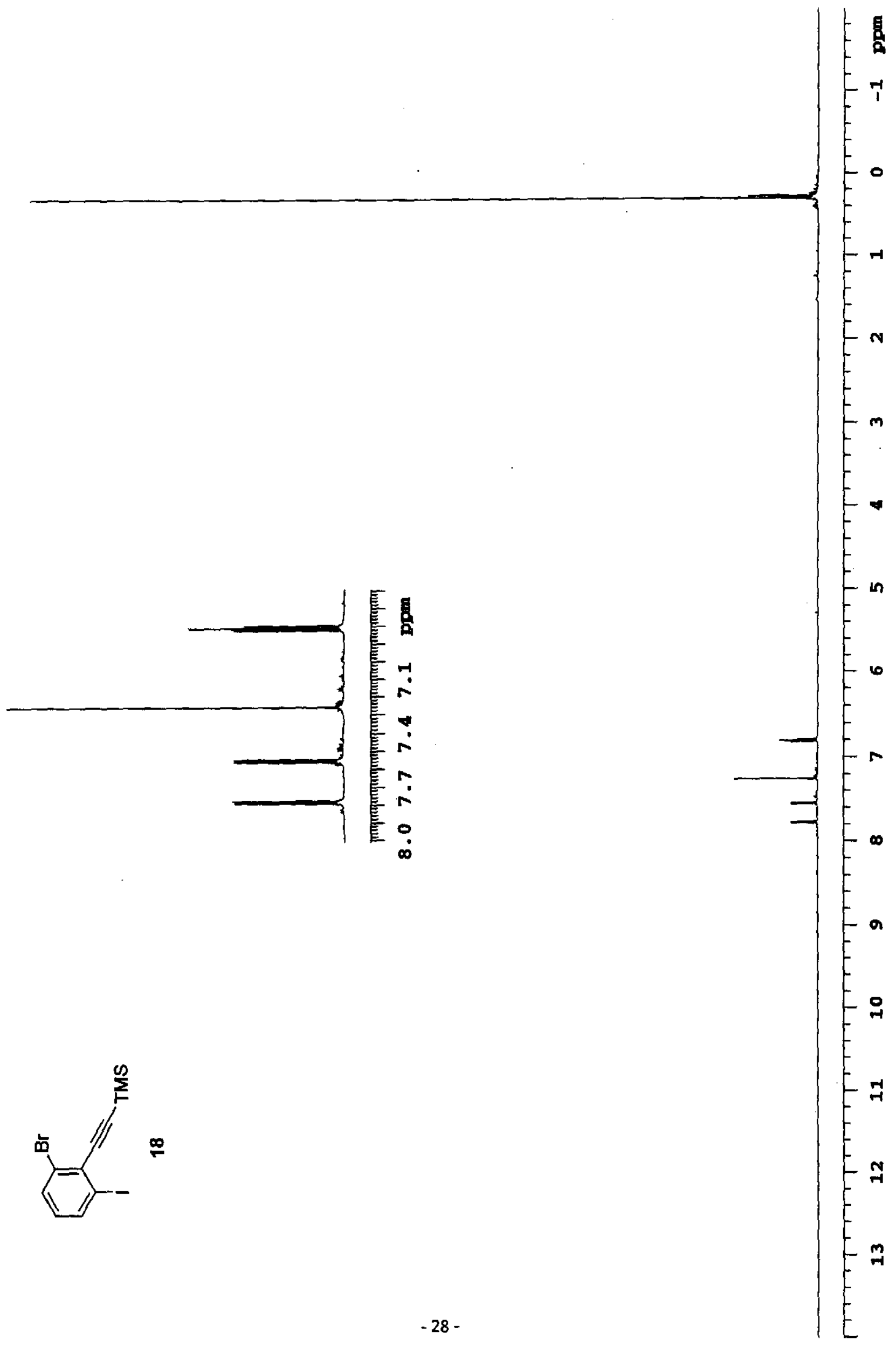




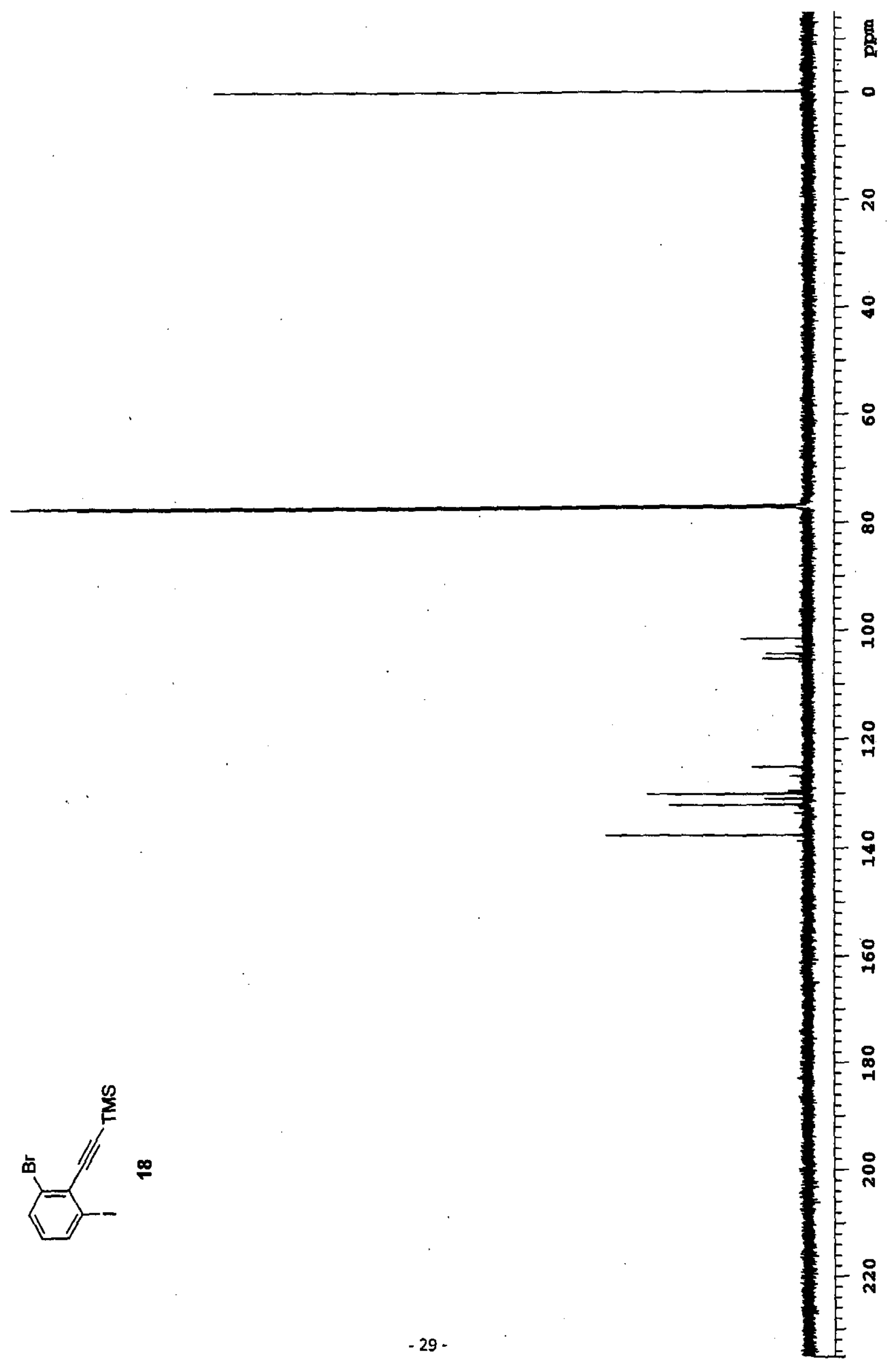




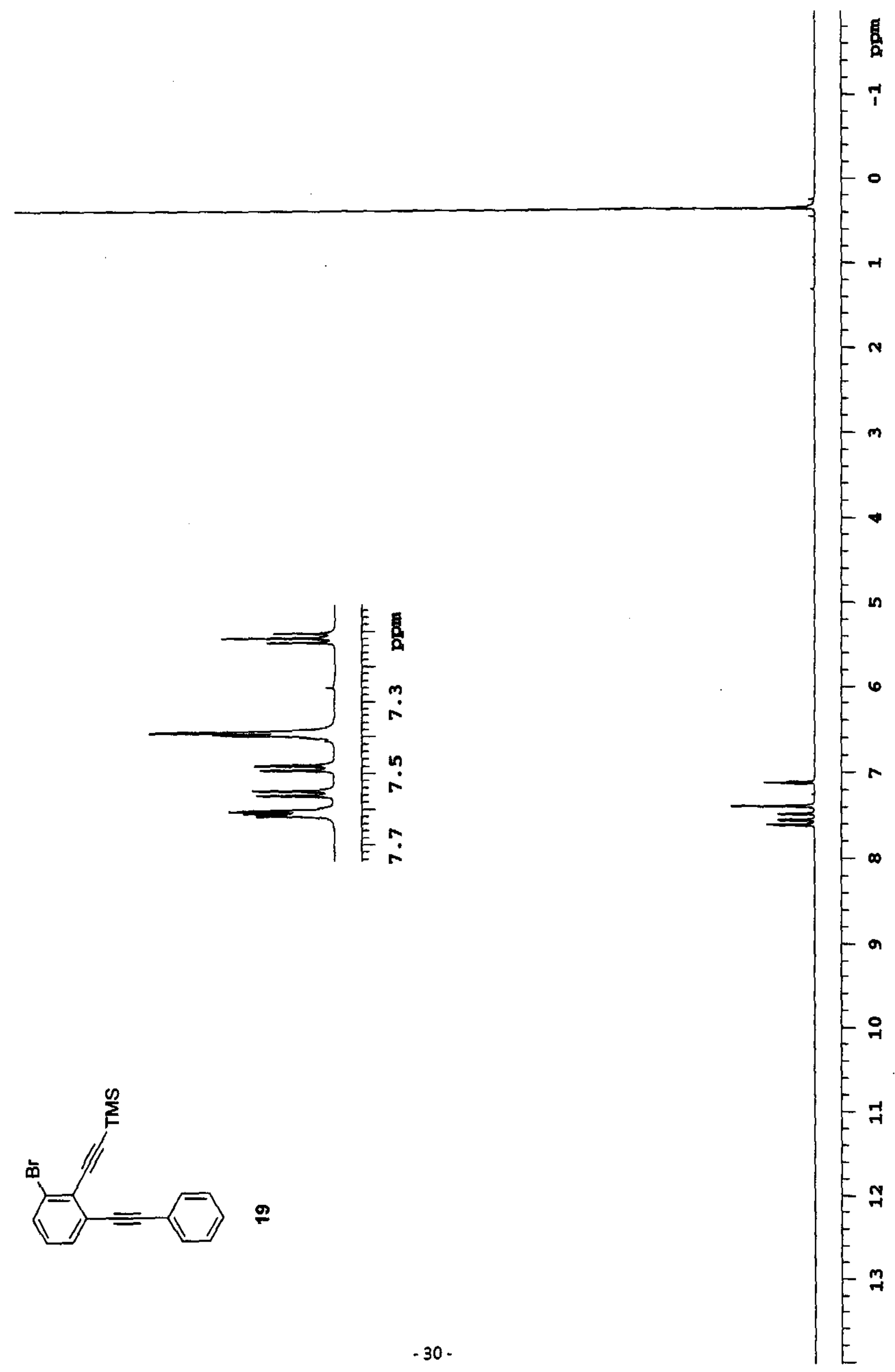




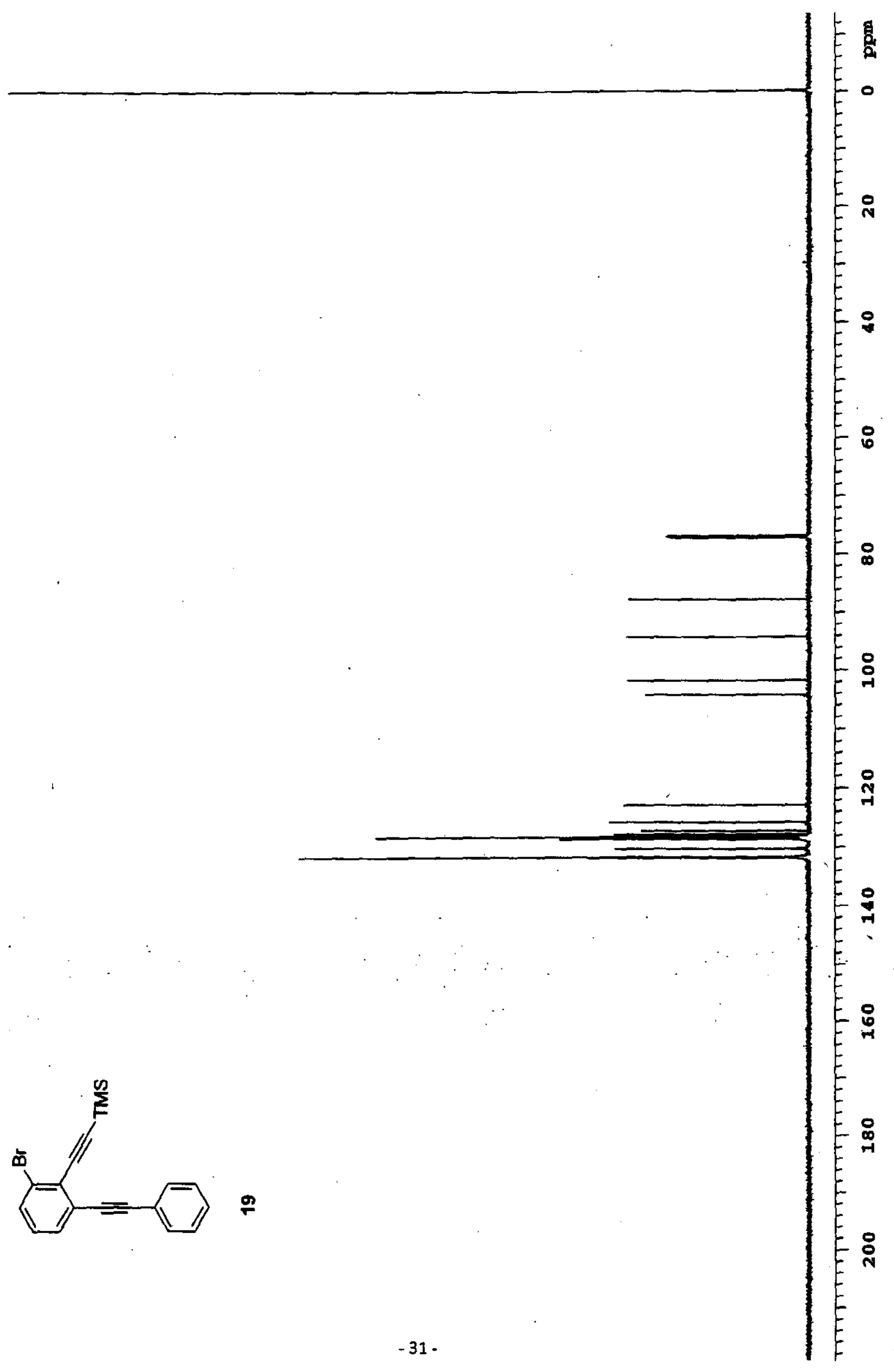




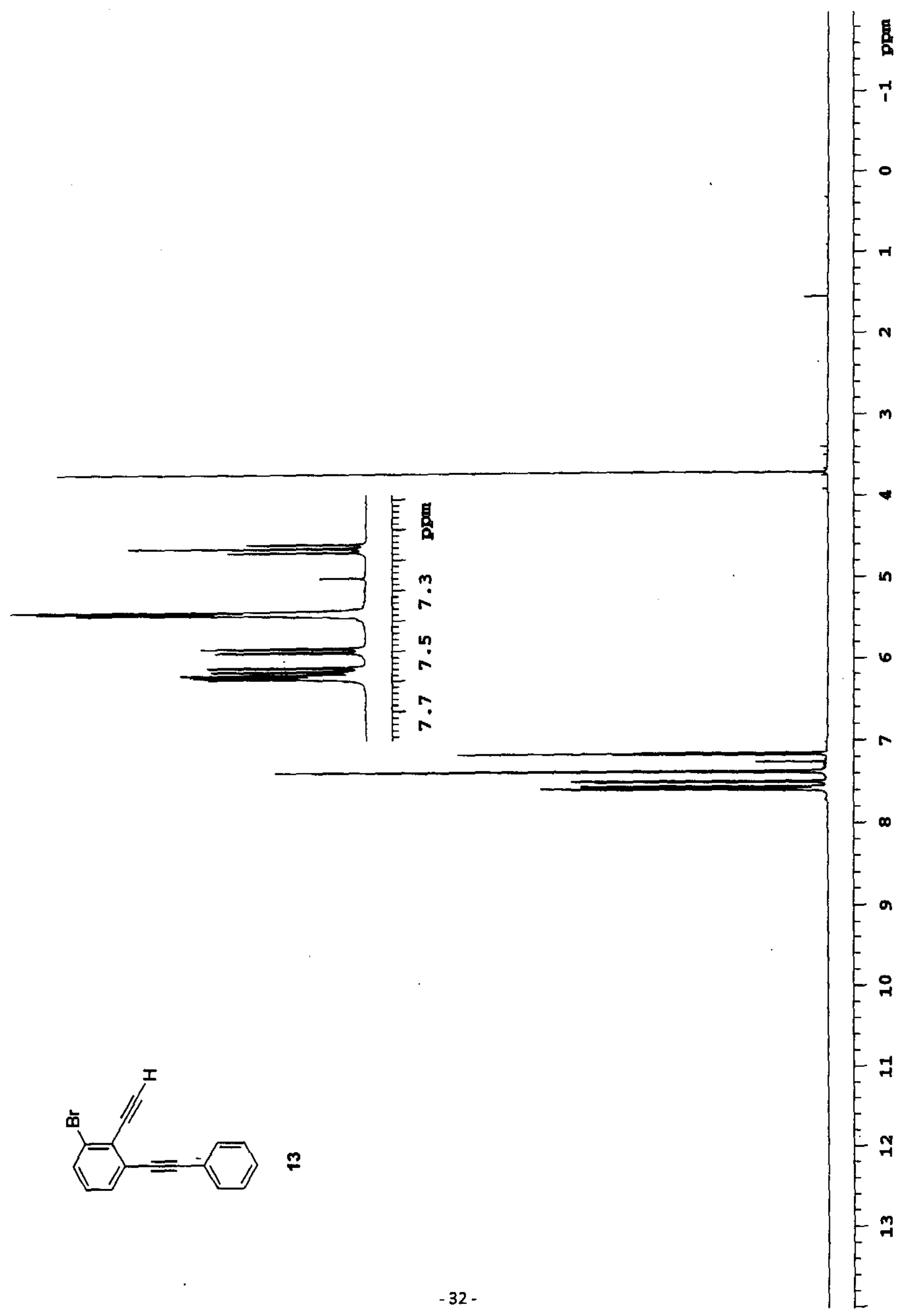




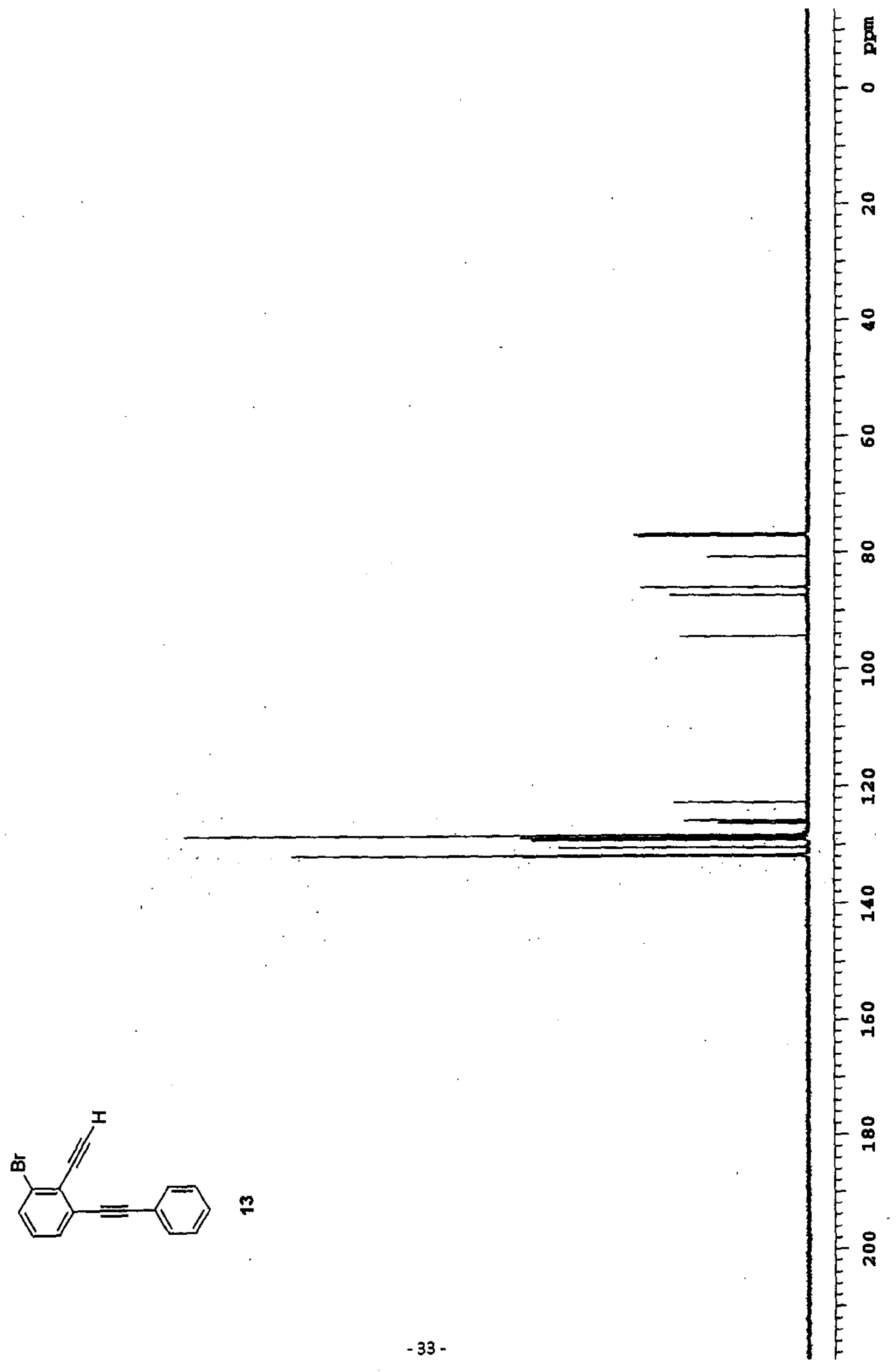




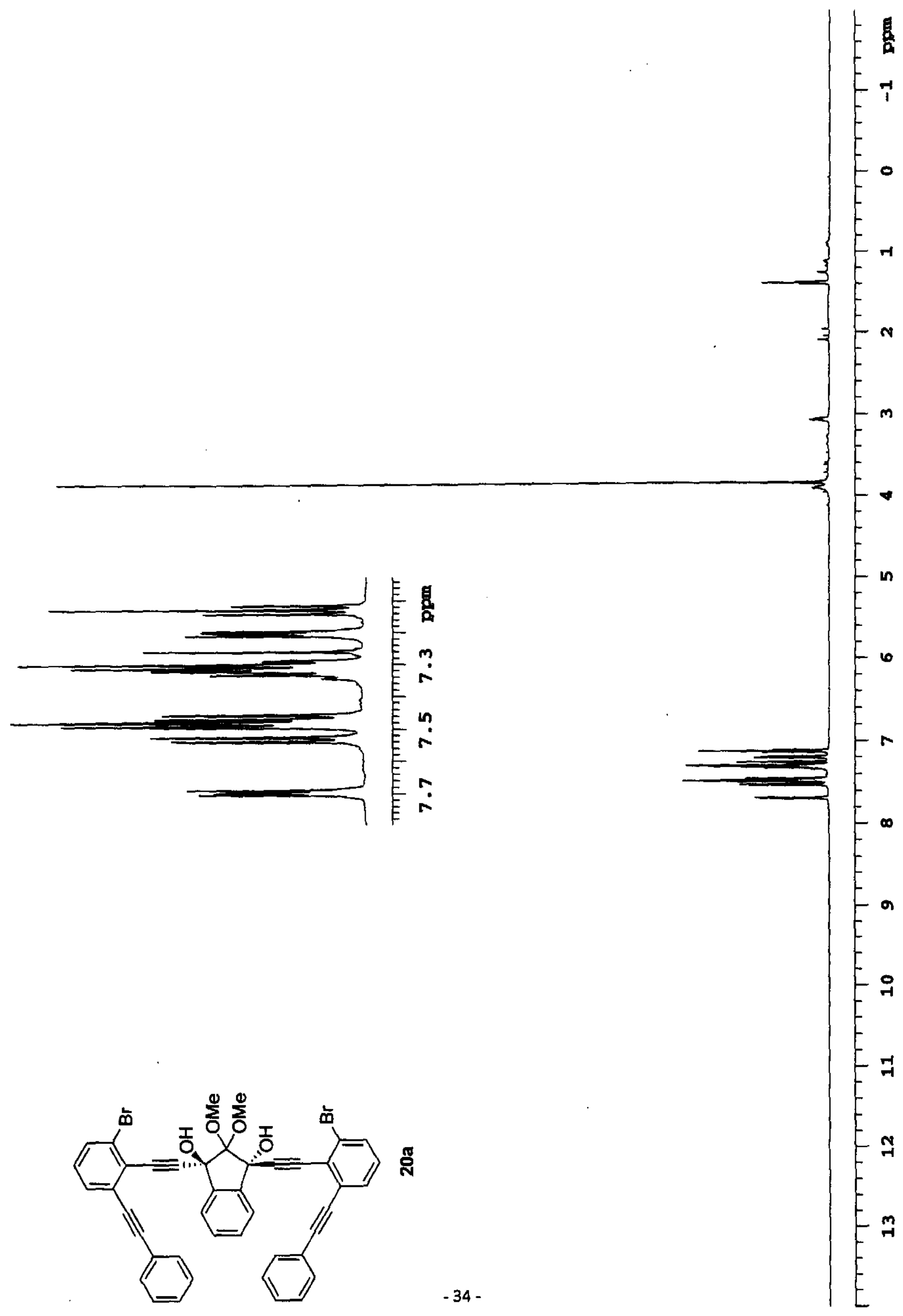




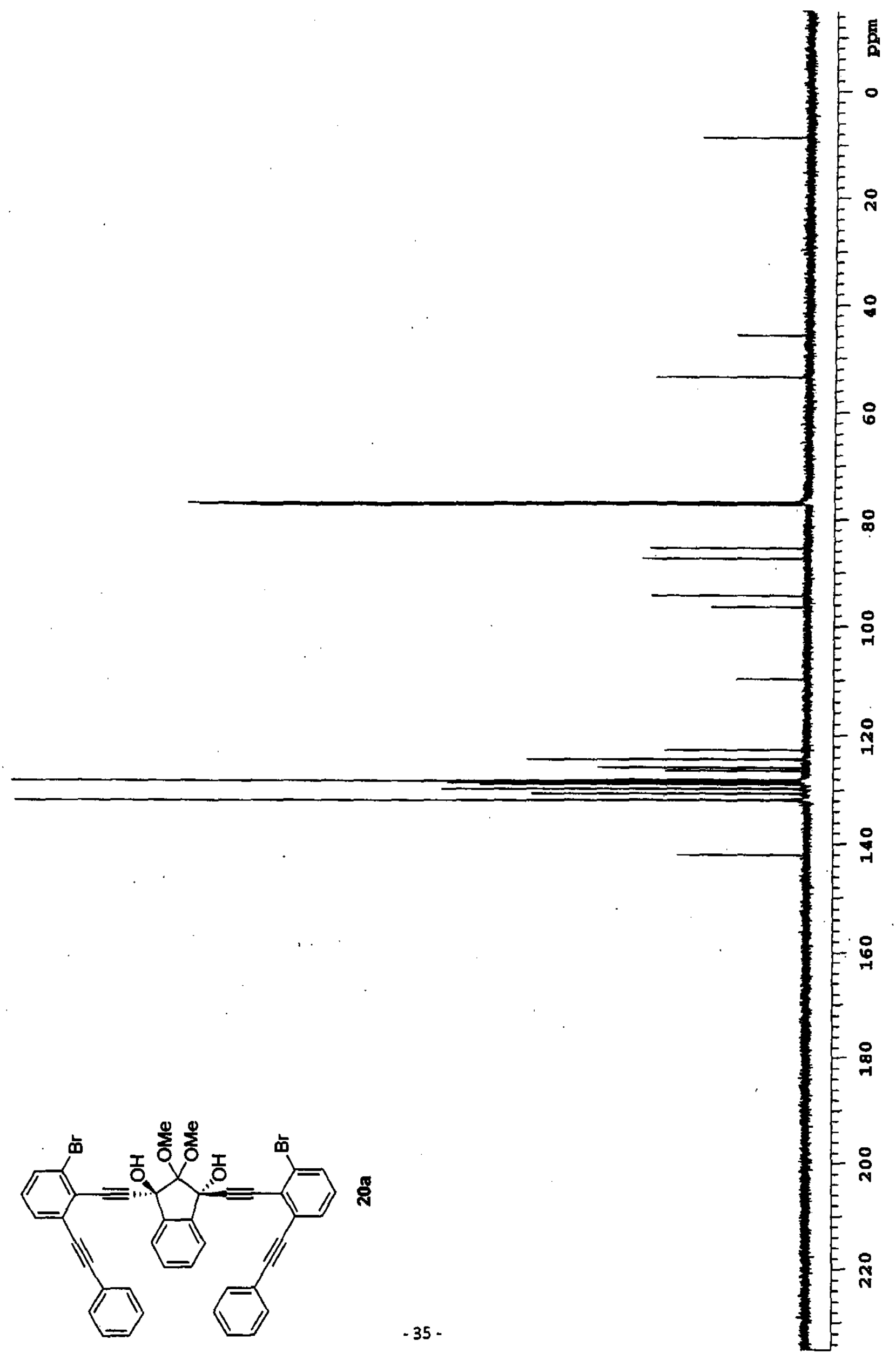




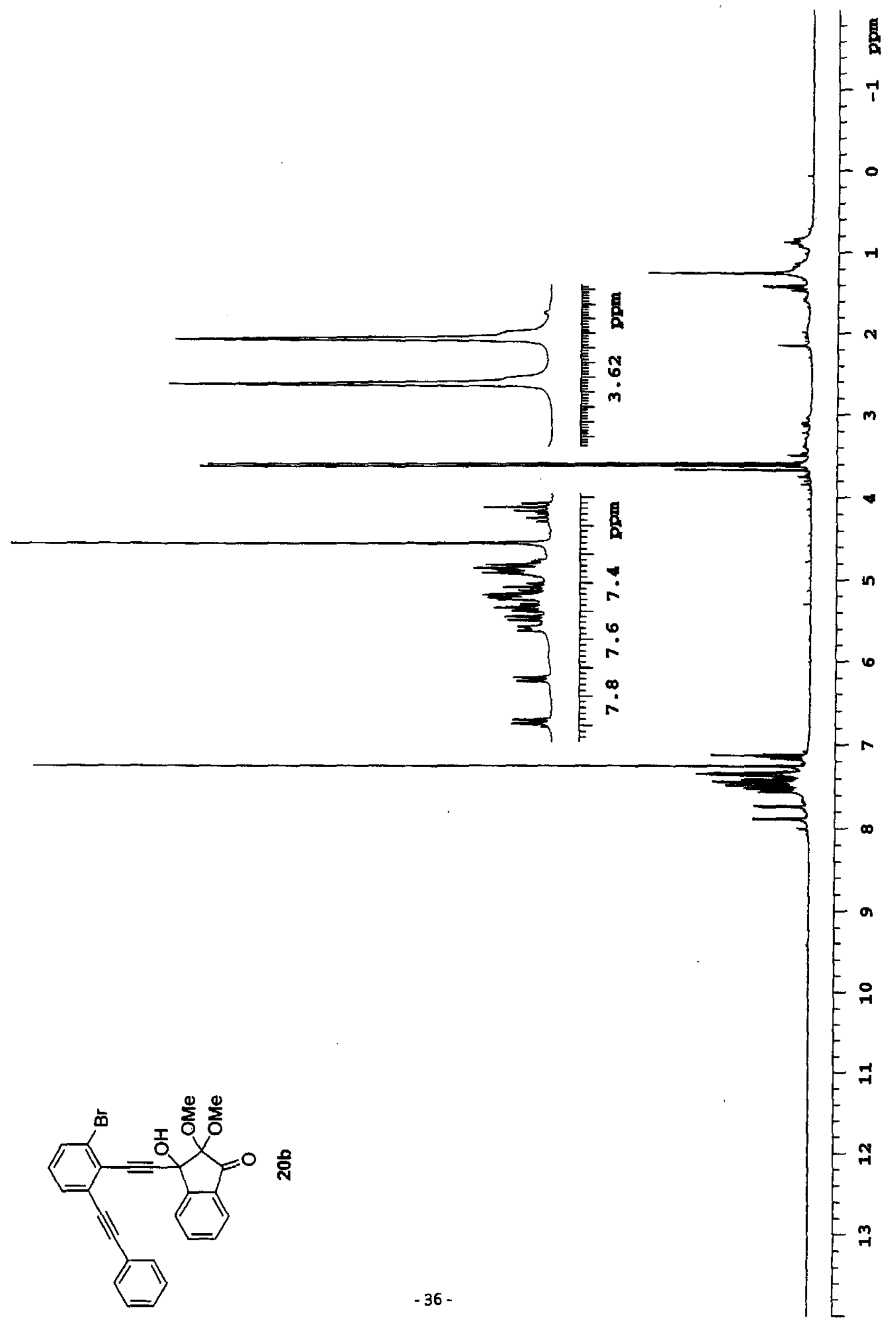




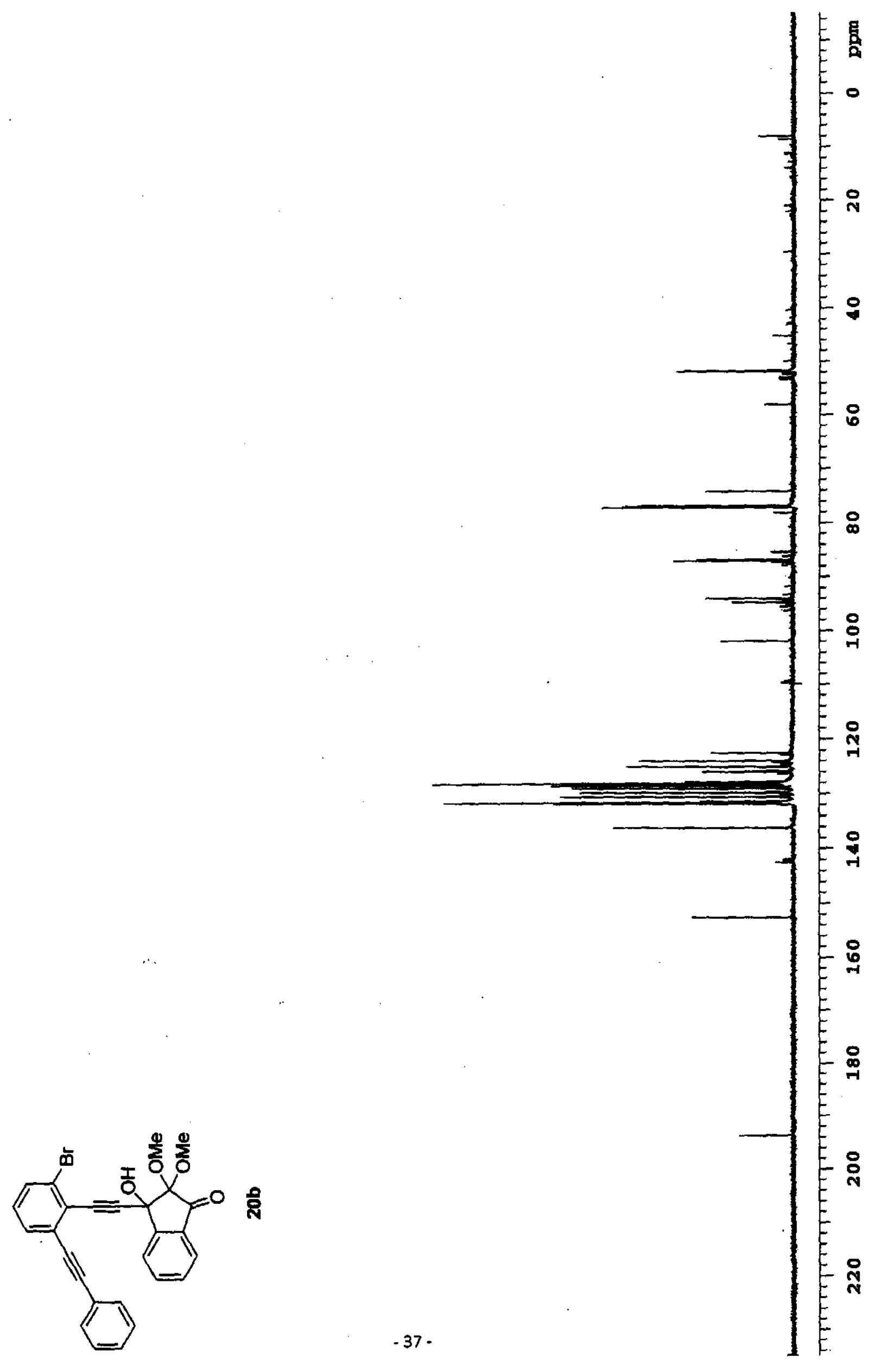




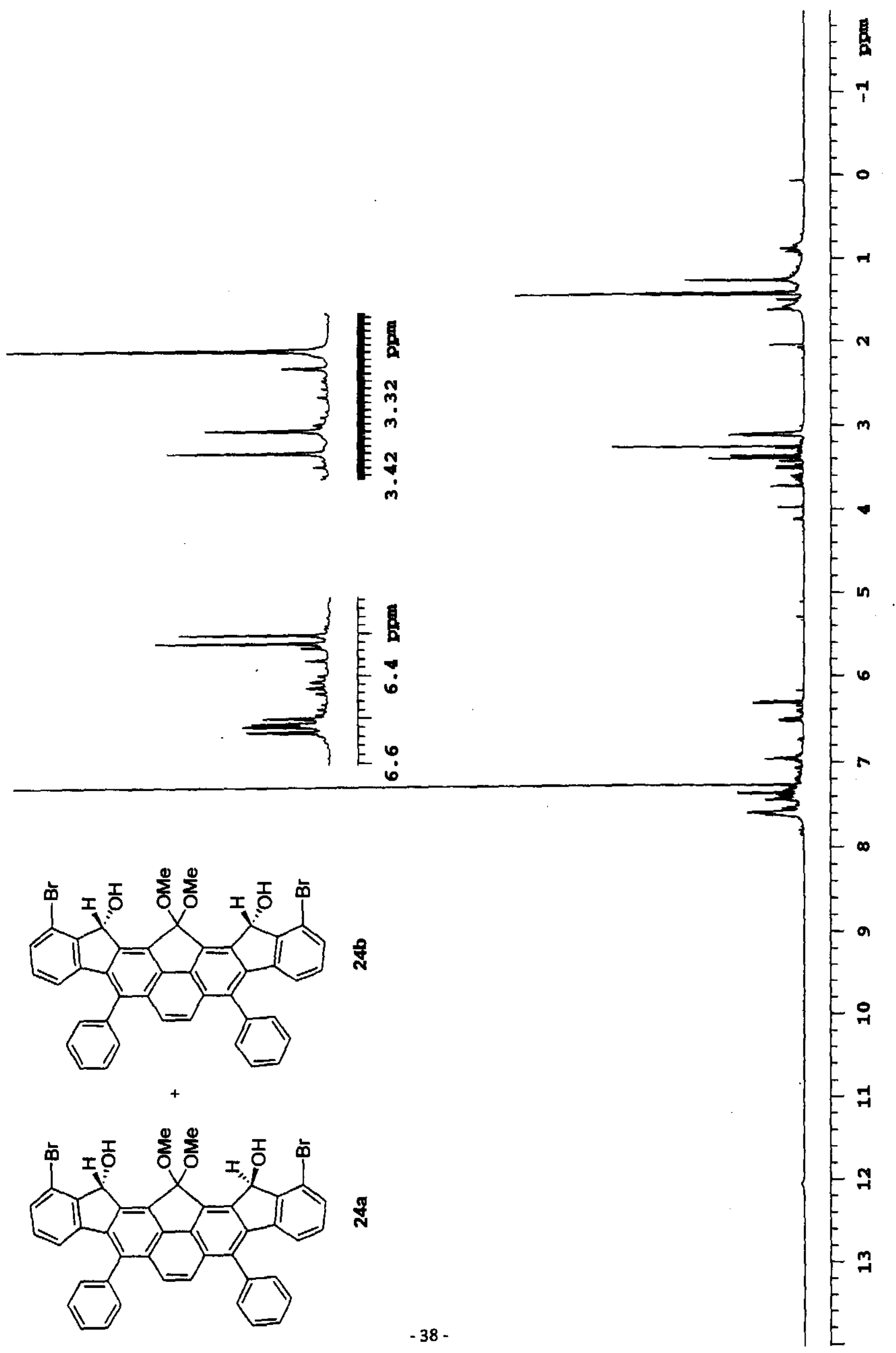




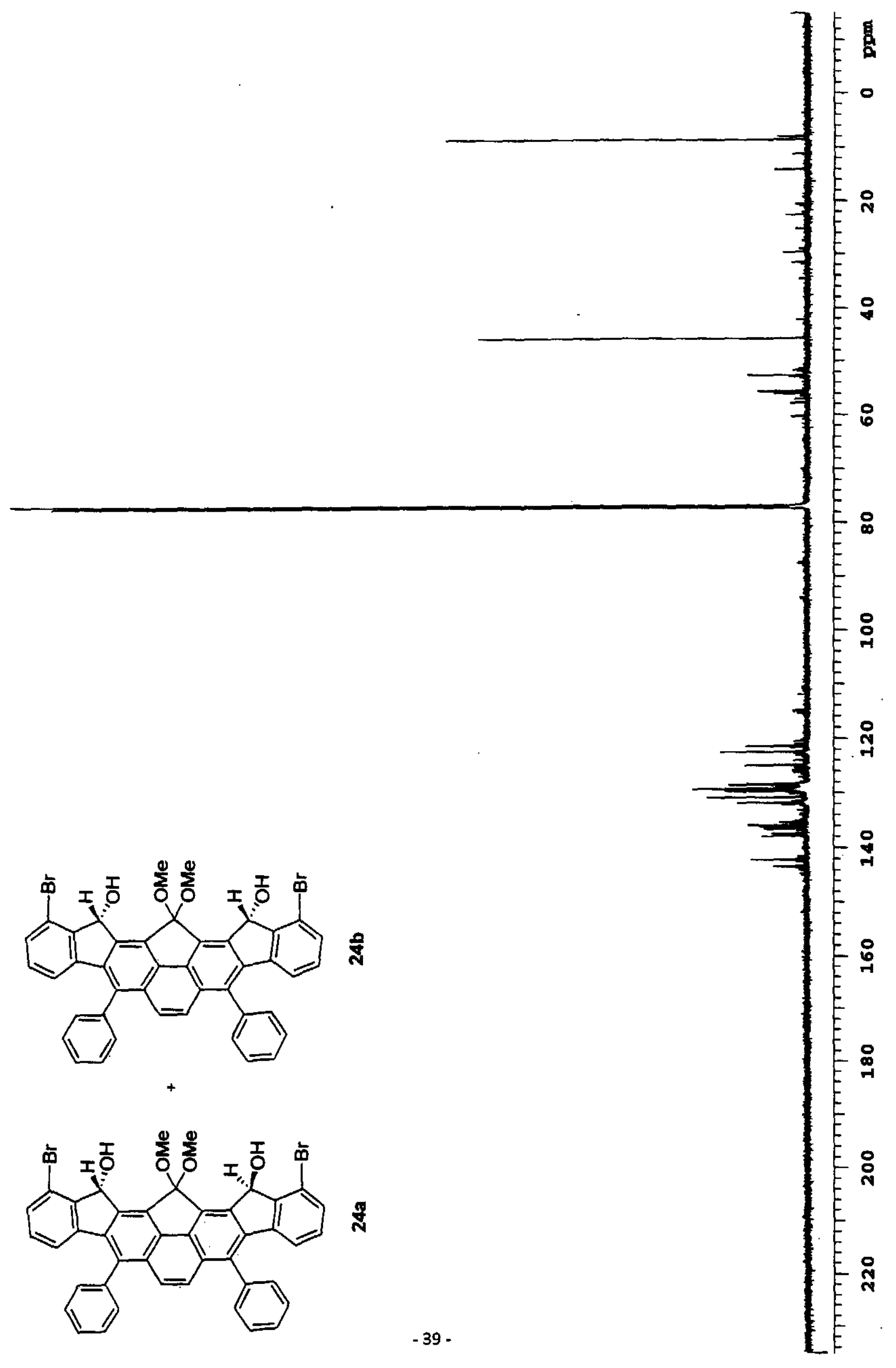


Development of Synthetic Pathways for Macrocyclic Acetylenes

Chi Yuan Tseng

Thesis submitted to the

Eberly College of Arts and Sciences

at West Virginia University

in partial fulfillment of the requirements

for the degree of

Master of Science

in

Chemistry

C. Eugene Bennett Department of Chemistry

APPROVAL OF THE EXAMINING COMMITTEE

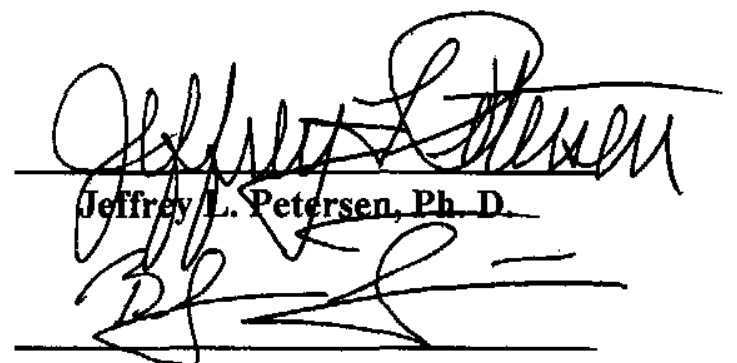

Björn C. G. Söderberg, Ph. D.

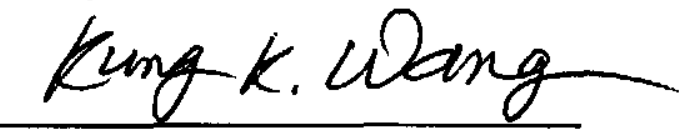

Kung K. Wang, Ph. D., Chair

$7 / 10 / 20 / 3$

Date 